\title{
Upaya Peningkatan Hasil Belajar Pendidikan Agama Islam dan Budi Pekerti Melalui Penggunaan Media Audio Visual dalam Pembelajaran Daring pada Siswa
}

\author{
Yasrida Yanti Sihombing ${ }^{1}$ \\ ${ }^{1}$ Dinas Pendidikan Daerah Kabupaten Tapanuli Selatan Provinsi Sumatera Utara, Sekolah Menengah Pertama Negeri 1 \\ Batangtoru, Indonesia
}

\begin{tabular}{l} 
Article Info \\
\hline Article history: \\
Received May $12^{\text {th }}, 2021$ \\
Revised Jun $20^{\text {th }}, 2021$ \\
Accepted Jul $26^{\text {th }}, 2021$ \\
\hline
\end{tabular}

\section{Keyword:}

Peningkatan hasil belajar Pendidikan agama islam dan budi Pekerti

Media audio visual

Pembelajaran daring

\begin{abstract}
Guru harus memastikan kegiatan belajar mengajar tetap berjalan, meskipun peserta didik berada di rumah. Solusinya, guru dituntut dapat mendesain media pembelajaran sebagai inovasi dengan memanfaatkan media daring (online). Pembelajaran yang efektif adalah pembelajaran yang mampu mengkondisikan subjek didik untuk mempunyai motivasi belajar, salah satunya kewajiban pendidik untuk memenuhi kewajiban tersebut adalah dengan memamfaatkan media dalam kegiatan pembelajaran. Diantara media yang dimaksud adalah media audio visual. Akan tetapi pada kenyataannya sistem pembelajaran daring, di SMP Negeri 1 Batangtoru bahwa guru masih minim menggunakan media audio visual dalam pemelajaran daring terhadap materi pembelajaran PAI. Rumusan masalah dalam penelitian ini adalah: Apakah Hasil Belajar PAI dan BP Dapat Ditingkatkan Melalui Penggunaan Media Audio Visual pada pembelajaran Daring Pada Siswa kelas IX-1 SMP Negeri 1 Batangtoru?. Penelitian ini merupakan penelitian tindakan kelas dengan menggunakan metode kualitatif. Data dikumpulkan melalui observasi dan tes, Objek penelitian ini adalah siswa kelas IX-1 SMPN I Batangtoru yang berjumlah 33 siswa. Penelitian ini dilaksanakan dalam tiga tahap yaitu tahap siklus I, siklus II dan siklus III. Pada tahap siklus I meningkat dibandingkan persentase ketuntasan klasikal prasiklus sebesar 39,39\% menjadi 60,61\%. namun belum mencapai indikator kinerja yang telah ditetapkan. Selanjutnya nilai rata-rata siswa setelah siklus II meningkatkan dengan 90,91\%. dan telah memenuhi indikator kinerja yang telah ditetapkan sebelumnya, yaitu $85 \%$ dan siswa telah mencapai nilai minimal 75 , maka disimpulkan bahwa pembelajaran PAI dan BP dengan materi zakat dengan menggunakan media audio visual khususnya semester ganjil kelas IX-1 SMP Negeri 1 Batangtoru tahun pelajaran 2020/2021, bahwa hasil belajar siswa dapat ditingkatkan.Hal ini bisa menjadi acuan bagi materi lainnya pada pembelajaran Pendidikan Agama Islam dan Budi Pekerti . Bahkan bisa menjadi acuan bagi mata pelajaran lainnya dalam melakukan pembelajaran baik daring maupun tatap muka.
\end{abstract}

(C) 2021 The Authors. Published by IICET.

This is an open access article under the CC BY-NC-SA license (https://creativecommons.org/licenses/by-nc-sa/4.0

\section{Corresponding Author:}

Sihombing, Y. Y.

Dinas Pendidikan Daerah Kabupaten Tapanuli Selatan Provinsi Sumatera Utara, Sekolah Menengah Pertama Negeri 1

Batangtoru, Indonesia

Email:1sntl@ccu.edu.tw 


\section{Introduction}

Sebagai upaya untuk mencegah pandemi Covid-19, pemerintah mengeluarkan kebijakan agar sekolah-sekolah meminta peserta didiknya untuk belajar di rumah. Mulai 16 Maret 2020 sekolah menerapkan metode pembelajaran peserta didik secara daring. Beberapa pemerintah daerah memutuskan menerapkan kebijakan untuk meliburkan peserta didik dan mulai menerapkan metode belajar dengan sistem daring (dalam jaringan) atau online. Kebijakan pemerintah ini mulai efektif diberlakukan di beberapa wilayah provinsi di Indonesia pada hari Senin, 16 Maret 2020 yang juga diikuti oleh wilayah-wilayah provinsi lainnya. Tetapi hal tersebut tidak berlaku bagi beberapa sekolah di tiap-tiap daerah. Sekolah-sekolah tersebut tidak siap dengan sistem pembelajaran daring, dimana membutuhkan media pembelajaran seperti handphone, laptop, atau komputer.

Sistem pembelajaran daring (dalam jaringan) merupakan sistem pembelajaran tanpa tatap muka secara langsung antara guru dan peserta didik tetapi dilakukan melalui online yang menggunakan jaringan internet. Guru harus memastikan kegiatan belajar mengajar tetap berjalan, meskipun peserta didik berada di rumah. Solusinya, guru dituntut dapat mendesain media pembelajaran sebagai inovasi dengan memanfaatkan media daring (online).

Hal ini sesuai dengan Menteri Pendidikan dan Kebudayaan Republik Indonesia terkait Surat Edaran Nomor 4 Tahun 2020 tentang Pelaksanaan Kebijakan Pendidikan dalam Masa Darurat Penyebaran Corona Virus Disease (COVID-19).Sistem pembelajaran dilaksanakan melalui perangkat personal computer (PC) atau laptop yang terhubung dengan koneksi jaringan internet. Guru dapat melakukan pembelajaran bersama diwaktu yang sama menggunakan grup di media sosial seperti WhatsApp (WA), telegram, instagram, aplikasi zoom ataupun media lainnya sebagai media pembelajaran. Dengan demikian, guru dapat memastikan peserta didik mengikuti pembelajaran dalam waktu yang bersamaan, meskipun di tempat yang berbeda.

Perkembangan ilmu pengetahuan pada saat ini khususnya dalam dunia pendidikan dituntut untuk bisa mengembangkan atau memajukan serta meningkatkan kualitas sumber daya manusia. Dalam hal ini pendidikan memiliki peranan yang sangat penting. Sumber daya manusia yang sesuai dengan kebutuhan pembangunan bangsa harus bisa dimunculkan dengan melahirkan suatu sistem pendidikan yang berkualitas berdasarkan filosofis bangsa. Oleh sebab itu, usaha untuk melahirkan suatu sistem pendidikan nasional yang berkualitas yang sesuai dengan kondisi negara yaitu berdasarkan pancasila harus terus dilaksanakan. Dan untuk mewujudkan pendidikan yang berkualitas, salah satu yang harus ada adalah guru yang memiliki kemampuan untuk mewujudkan tujuan pendidikan nasional yakni memiliki kompetensi paedagogik, kompetensi.

Kepribadian, kompetensi sosial, dan kompetensi profisional (UU RI NO.14 Tahun 2005 tentang Guru dan Dosen). (Yhudi Munadi, 2010)

Guru merupakan komponen pembelajaran yang memegang peranan penting dan utama, karena keberhasilan proses belajar mengajar sangat ditentukan oleh faktor guru. Tugas guru adalah menyampaikan materi pelajaran kepada siswa melalui interaksi komunikasi dalam proses belajar mengajar yang dilakukannya. Keberhasilan guru dalam menyampaikan materi sangat tergantung pada kelancaran interaksi komunikasi antara guru dengan siswanya. Ketidak lancarankomunikasi membawa akibat terhadap pesan yang diberikan guru. Untuk itu seorang guru dituntut untuk memiliki kompetensi paedagogik yaitu memiliki kemampuan secara metodologis dalam hal perancangan dan pelaksanaan pembelajaran. Termasuk di dalamnya penguasaan dalam penggunaan media pembeajaran.

Penggunaan media atau alat bantu disadari oleh banyak praktisi pendidikan sangat membantu aktivitas proses pembelajaran baik di dalam maupun di luar kelas, terutama membantu meningkatkan hasil belajar siswa. Proses pembelajaran akan berjalan efektif jika berlangsung dalam kodisi dan situasi yang kondusif, menarik, nyaman dan menyenangkan.

Oleh kerena itu, guru dituntut untuk dapat memanfaatkan dan menggunakan peralatan yang lebih ekonomis, dan efisien serta melakukan usaha-usaha inovasi dalam pembelajaran.

Pendidikan Agama Islam merupakan upaya sadar dan terencana dalam menyiapkan peserta didik untuk mengenal, memahami, menghayati, mengimani, dan saling menghormati. Serta usaha untuk membina dan mengasuh peserta didik agar senantiasa memahami ajaran Islam secara menyeluruh, yang pada akhirnya dapat mengamalkan serta menjadikan Islam sebagai pedoman hidup. Dengan demikian guru PAI sebagai pendidik yang menggunakan media harus menguasai dan mengetahui eksistensi penggunaan media tersebut, penguasaan guru dalam penggunaan media adalah bagian yang penting, sebab apabila hal-hal tersebut tidak di perhatikan dengan baik, maka proses belajar mengajar tidak akan berlangsung secara optimal serta tidak tercapai tujuan kurikulum yang telah ditentukan, sebab dalam hal ini siswa maupun guru tidak akan terjadi komunikasi belajar mengajar yang baik. 
Hasil belajar selalu dinyatakan dalam bentuk perubahan tingkah laku. Bagaimana bentuk tingkah laku yang diharapkan berubah itu dinyatakan dalam perumusan tujuan pembelajaran. Hasil belajar meliputi tiga aspek yaitu, kognitif, afektif, piskomotorik. Semua hasil belajar pada dasarnya harus dapat dievaluasi. Penilaian hasil belajar peserta didik yang dilakukan oleh guru selain untuk memantau proses, kemajuan dan perkembangan hasil nilai peserta didik sesuai dengan potensi yang dimiliki, juga sekaligus sebagai umpan balik kepada guru agar dapat menyempurnakan perencanaan dan proses program pembelajaran.

Mencermati kegiatan pembelajaran PAI pada siswa kelas IX-1 SMP Negeri 1 Batangtoru, tampak bahwa metode yang digunakan guru dalam daring hanya metode pemberian tugas. Penggunaan metode penugasan ini secara terus menerus tentu tidak relevan mengingat kompleksitas materi PAI yang sebagian materinya bersifat aplikatif seperti tata cara berwudu', tayammum, tata cara sholat, dan lain-lain. Untuk dapat mengoptimalkan penguasaan peserta didik pada materi-materi tersebut tentu tidak cukup dengan hanya menghafalkan konsepnya saja tetapi harus diperagakan dan yang terpenting adalah siswa harus dilibatkan secara aktif untuk memperagakan keterampilan spesifik yang dipelajari di kelas. Disinilah pentingnya pemilihan metode yang tepat yang harus disesuaikan dengan karakteristik materi pelajaran.

Selain itu, hasil pengamatan awal penulis pada siswa kelas IX-1 SMP Negeri 1 Batangtoru menunjukkan bahwa pengelolaan pembelajaran cenderung membuat peserta didik pasif dalam belajar sehingga pembelajaran bersifat searah dan cenderung membosankan bagi peserta didik. Hal tersebut tampak dari rendahnya keterlibatan peserta didik selama pembelajaran berlangsung seperti tidak adanya umpan balik dari peserta didik untuk menanyakan materi mata pelajaran yang kurang jelas, kurangnya perhatian peserta didik dalam mengikuti pembelajaran, bahkan beberapa peserta didik ada yang tidak mengerjakan tugas yang diberikan dengan alasan belum faham akan tugas yang diberikan.

Fenomena pembelajaran yang demikian itu, memicu kemerosotan hasil belajar peserta didik pada mata pelajaran PAI. Dilihat dari nilai rata-rata peserta didik kelas IX-1 SMP Negeri 1 Batangtoru pada mata pelajaran PAI menujukkan 15 siswa mendapatkan nilai 60 dari 33 siswa padahal kriteria ketuntasan minimal (KKM) di sekolah yaitu 70. Hal ini artinya pencapaian hasil belajar peserta didik belum mencapai nilai KKM. (Observasi Prapenelitian)

Dengan demikian dapat dipahami bahwa penggunaan media bukan hanya membantu guru dalam mengajar, tetapi lebih dari pada itu yakni sebagai usaha yang bertujuan untuk memudahkan siswa dalam mempelajari pelajaran pada umumnya dan pembelajaran Pendidikan Agama Islam pada khususnya. Sehingga penulis akan mencoba menulis Laporan Penelitian Tindakan Kelas yang berjudul "Upaya Peningkatan Hasil Belajar Pendidikan Agama Islam Dan Budi Pekerti Melalui Penggunaan Media Audio Visual Dalam Pembelajaran Daring Pada Siswa".

\section{Kajian Pustaka}

\section{Hakikat Hasil Belajar}

\section{Pengertian Hasil Belajar}

Belajar merupakan suatu perubahan yang terjadi melalui latihan atau pengalaman. Perubahan itu tidak hanya berkaitan dengan penambahan ilmu pengetahuan saja, tetapi lebih dari itu belajar untuk membentuk kecakapan kerterampilan, dan penyusaian diri. Menurut Thorndike yang dikutip oleh Ahmad tafsir menyatakan bahwa "belajar adalah suatu usaha yang memecahkan problem berdasarkan eksperimen yang dilakukannya". Menurut Nana Sudjana menyatakan bahwa "hasil belajar adalah kemampuan-kemampuan yang dimiliki siswa setelah ia menerima pengalaman belajarnya". Penilaian hasil belajar dicatat dalam bentuk angka yang didapat sesuai dengan pencapaian dari tugas akademik. Sedangkan menurut Arikunto, hasil belajar adalah hasil yang dicapai seseorang setelah melakukan kegiatan ejar dan merupakan penilaian yang dicapai seorang siswa untuk mengetahui sejauh mana bahan pelajaran atau materi yang sudah diajarkan siswa.

Dick dan Reise mengemukakan bahwa hasil belajar adalah kemampuan-kemampuan yang dimiliki siswa sebagai hasil kegiatan pembelajaran, yang terdiri atas empat macam, yaitu: pengetahuan, kemampuan intelektual, keterampilan motorik dan sikap. Sementara Bloom, membedakan hasil belajar menjadi tiga ranah, yaitu ranah kognitif (pengetahuan), ranah afektif (sikap), dan ranah psikomotorik (keterampilan motorik). Hasil belajar juga berkaitan dengan pencapaian dalam memperoleh kemampuan sesuai dengan tujuan khusus yang direncanakan. Dengan demikian tugas utama guru dalam kegiatan ini adalah merencanakan instrumen yang dapat menyimpulkan tentang data tentang keberhasilan siswa mencapai tujuan pembelaajaran. Berdasarkan data tersebut guru dapat mengembangkan dan memperbaiki program pembelajaran sedangkan tugas disainer dalam menentukan hasil belajar selain menentukan instrumen juga perlu merancang cara menggunakan instrument beserta 
kriteria keberhasilannya. Hasil belajar merupakan perubahan atau penilaian yang dimiliki siswa setelah memenuhi tugas akademik sebelumnya.

2. Faktor-Faktor Yang Mempengaruhi Hasil Belajar

Ada beberapa faktor yang mempengaruhi hasil belajar siswa antara lain :

a. Faktor-faktor dari dalam (internal)

1) Faktor jasmani

Kondisi fisik merupakan faktor yang dapat mempengaruhi siswa dalam proses belajar PAI, siswa yang dalam kondisi sehat jasmaninya akan berbeda dengan siswa yang tidak sehat jasmaninya, karena belajar memerlukan kecakapan, keterampilan dan kemampuan berpikir, selain itu ketidak sempurnaan panca indera juga dapat mempengaruhi prestasi belajar siswa, misalnya : cacat mata, telinga dan sebagainya. Karena kualitas panca indera merupakan syarat bagi suatu proses pembelajaran adalah pendengaran dan penglihatan.

2) Faktor psikologis

a. Bakat

Bakat juga merupakan faktor internak yang banyak mempengaruhi prestasi belajar siswa, setiap bakat inilah yang dapat memungkinkan siswa berkembang sesuai dengan keinginannya, setiap manusia memiliki bakat yang berbeda-beda, untuk mengembangkan bakat yang dimiliki, seorang harus mendapatkan bimbingan dan pengarahan yang efektif sebab kalau tidak, maka bakat tersebut tidak dapat berkembang.

b. Kecerdasan

Setiap individu yang lahir memiliki kecerdasan yang berbeda- beda, kecerdasan dapat mempengaruhi cara berpikir dan kemampuan beradaptasi dengan berbagai masalah yang dihadapi, oleh karena itu siswa akan berhasil jika dalam dirinya ada dorongan untuk belajar.

c. Minat

Minat adalah suatu gejara psikis yang ada pada seseorang yang direleasasikan dengan senang dan menunjukkan perhatian dengan perasaan dan perhatian yang berpusat pada suatu obyek. Sehingga seseorang tersebut mempunyai kecenderungan untuk melakukannya dan belajar dapat berjalan dengan baik bila disertai dengan minat.

\section{d. Intelegensi}

Intelegensi adalah kecapan yang terdiri dari tiga jenis yaitu kecakapan untuk menghadapi dan menyesuaikan kedalam situasi yang baru dengan cepat dan efektif, mengetahui menggunakan konsep- konsep yang abstrak secara efektif, mengetahui relasi dan mempelajarinya dengan cepat.

b. Faktor-faktor dari luar pelajaran (eksternal), yang termasuk dalam faktor eksternal yaitu :

1. Faktor keluarga

Siswa yang belajar akan menerima pengaruh dari keluarga berupa: cara orang tua mendidik, relasi antara anggota keluarga, suasana rumah tangga dan keadaan ekonomi keluarga.

2. Faktor sekolah

Faktor sekolah yang mempengaruhi belajar ini mencakup metode mengajar, kurikulum, relasi guru dengan siswa, relasi siswa dengan siswa, disiplin sekolah pelajaran dan waktu sekolah, standar pelajaran, keadaan gedung, metode belajar dan tugas rumah.

\section{Faktor masyarakat}

Masyarakat sangat berpengaruh terhadap belajar siswa karena keberadaannya siswa dalam masyarakat. Seperti kegiatan siswa dalam masyarakat, media juga berpengaruh terhadap positif dan negatifnya, pengaruh dari teman bergaul siswa, dan kehidupan masyarakat disekitar siswa juga berpengaruh terhadap belajar siswa. 
Dengan memahami faktor-faktor yang mempengaruhi proses belajar dalam diri peserta didik, sekiranya akan memudahkan para pendidik atau orang tua untuk menentukan metode yang tepat pada proses pembelajaran.

3. Aspek-Aspek Hasil Belajar

Secara umum belajar diartikan sebagai perubahan tingkah laku. Belajar tidak ada warnanya jika tidak menghasilkan pengetahuan, pembentukan sikap dan keterampilan. Oleh karena itu proses belajar mengajar harus mendapat perhatian yang serius dengan melibatkan berbagai aspek yang menunjang keberhasilan belajar mengajar, yakni aspek kognitif, afektif dan psikomotorik.

\section{a. Aspek Kognitif}

Taksonomi tujuan pengajaran dalam kawasan kognitif menurut Bloom terdiri atas enam level yaitu sebagai berikut : a) Pengetahuan (knowledge), yaitu meliputi menyebutkan, menampilkan, dan menjelaskan; b) Pemahaman (comprehension), yaitu meliputi menjelaskan, mengurutkan, dan memberi contoh; c) Penerapan (aplication), yaitu meliputi menerapkan, menyerasikan. Analisis (analysis), yaitu pada taraf memahami proses dan cara kerjanya suatu proses; d) Sintesis (synthesis), yaitu menyatukan dari berbagai unsur menjadi satu; e) Evaluasi (evaluation), yaitu mampu menjawab pertanyaan guru.

b. Aspek Afektif

Yaitu aspek yang berhubungan dengan pembangkitan minat sikap/ emosi juga penghormatan (kepatuhan) terhadap nilai atau norma. Dalam aspek afektif terdiri atas lima level, yaitu : a) Penerimaan (receiving/ attending), yaitu memperhatikan, menyimak dan mendengarkan; b) Penanggapan (responding), yaitu dengan mengajukan pertanyaan, dan menjawab pertanyaan; c) Penilaian (valuing), yaitu dengan ditandai penerimaan terhadap nilai yang diperoleh; d) Pengorganisasian (organizing), yaitu dengan memilah-milah nilai yang diperoleh, dan menjadikan motivasi untuk menjadi lebih baik; e) Karakteristik (characterization), yaitu dengan terbentuknya karakter seseorang.

c. Aspek Psikomotorik

Yaitu pengajaran yang bersifat keterampilan atau yang menunjukan gerak, keterampilan tangan, menunjukkan pada tingkat keahlian seseoang dalam suatu tugas atau kumpulan tugas tertentu. Aspek ini menjadi lima level, yaitu : a) Kesiapan (set), yaitu dengan menyiapkan alat untuk demonstrasi, kesiapan dalam menerima pelajaran; b) Meniru (imitation), yaitu dengan melakukan sesuatu sesuai dengan contoh yang diamati; c) Membiasakan (habitual), yaitu dapat melakukan sesuatu tanpa melihat contoh; d) Menyesuaikan (adaption), yaitu dapat menguasai gerakangerakan tertentu; e) Menciptakan (originatio), yaitu sudah sampai pada taraf mahir, dapat membuat variasi sendiri.

Untuk mencapai keberhasilan belajar ketiga aspek tersebut tidak bisa dipisahkan, namun jauh lebih baik jika dihubungkan. Penggabungan tiga aspek tersebut akan dapat diketahui kualitas keberhasilan pembelajaran. Hasil belajar merupakan bukti keberhasilan yang telah dicapai seorang peserta didik. Setiap pembelajaran dapat menimbulkan suatu perubahan yang khas. Hasil belajar secara luas tentu mencakup ketiga kawasan tujuan pendidikan tersebut yaitu kognitif, afektif dan psikomotorik.

\section{Konsep Pendidikan Agama Islam}

1. Pengertian Pendidikan Agama Islam

Pendidikan agama Islam adalah usaha sadar untuk menyiapkan peserta didik dalam menyakini, memahami, menghayati dan mengamalkan Agam Islam melalui kegiatan bimbingan, pengajaran, dan atau latihan dengan memperhatikan tuntutan untuk menghormati agama lain dalam hubungan kerukunan antar umat beragam dalam masyarakat untuk mewujudkan persatuan.

Pendidikan Agama Islam adalah pendidikan dengan melalui ajaran agama Islam, yaitu berupa bimbingan dan usaha terhadap anak didik agar nantinya setelah selesai dari pendidikan ia dapat memahami, menghayati dan mengamalkan ajaran-ajaran Agama Islam yang telah diyakini secara menyeluruh, serta menjadikan ajaran Agama Islam itu sebagai suatu pandangan hidupnya demi keselamatan dan kesejahteraan hidup di dunia maupun di akhirat kelak.

Selanjutnya Pendidikan Agama Islam adalah "usaha yang sistematis dan praktis dalam membantu anak didik agar mereka sesuai dengan ajaran Islam". Pendidikan Agama Islam adalah suatu 
bimbingan dan atau latihan untuk mencapai tujuan yang hendak dicapai. Kegiatan yang dilaksanakan untuk meningkatkan keyakinan pemahaman atau penghayatan dan pengalaman ajaran Islam dari peserta didik yang selain untuk membentuk kesalihan dan kualitas pribadi yang menyangkut hubungan pribadi serta kesolihan sosial.

Beberapa pengertian Pendidikan Agama Islam di atas dapat disimpulkan bahwa Pendidikan Agama Islam adalah usaha terencana untuk membimbing peserta didik agar menjadi manusia beragama dan menjalankan ajaran Agama Islam dari sumber utamanya sehingga terjalin kebahagiaan di dunia dan akhirat, bertujuan untuk terbentuknya kepribadian yang berguna bagi dirinya, masyarakatnya dan lingkungannya.

2. Tujuan Pendidikan Agama Islam

Tujuan umum dari Pendidikan Agama Islam adalah menjadikan umat muslim sejati, beriman yang teguh, beramal saleh, dan berakhlak mulia serta berguna bagi masyarakat, agama dan negara. Sedangkan tujuan khusus di sekolah antara lain : a) Penanaman rasa beragama; b) Penanaman rasa cinta pada allah dan rasulnya; c) Memperkenalkan Agama Islam yang global yaitu mengenai rukun iman, rukun Islam dan syariat; d) Membiasakan anak berakhlak mulia; e) Membiasakan contoh tauladan yang baik.

Tujuan khusus di atas mencakup tiga aspek dalam ajaran Islam. Aspek tersebut akidah yang berupa rasa cinta kepada allah dan rasulnya, aspek akhlak yaitu berakhlak mulia dan aspek sosial yaitu jiwa beragama. Adapun tujuan pendidikan agama islam meliputi 4 aspek yaitu : a) Aspek Jasmani. Tujuan pada aspek ini adalah terbentuknya muslim yang sehat dan kuat; b) Aspek rohani. Tujuan pada aspek ini adalah membentuk muslim yang berpribadi baik, baik terhadap diri orang lain maupun lingkungan sekitar; c) Aspek akal. Tujuan pada aspek ini membentuk muslim yang cerdas. Mempunyai wawasan yang luas dan pemikiran yang tajam serta tidak mudah diombang-ambingkan oleh orang lain; d) Aspek sosial. Pada aspek ini muslim mampu bersosialisasi baik dengan orang lain dan mampu mengubah lingkungan sekitarnya sesuai aturan yang ditetapkan oleh ajaran Islam.

Tujuan akhir dari Pendidikan Agama Islam adalah terbentuknya muslim yang bahagia di dunia dan akhirat. Meskipun demikin tidak dipungkiri bahwa untuk mencapai tujuan akhir tersebut ada tujuan-tujuan sementara yang harus dipenuhi oleh peserta didik. Pendidikan agama Islam disekolah adalah bertujuan untuk meningkatkan keyakinan, pemahaman, penghayatan dan pengalaman peserta didik tentang ajaran Agama Islam sehingga menjadi manusia muslim yang beriman dan bertakwa kepada Allah SWT dan berakhlak mulia dalam kehidupan pribadi, bermasyarakat, berbangsa dan bernegara.

3. Fungsi Pendidikan Agama Islam

Fungsi Pendidikan Agama Islam antara lain : a) Fungsi pengembangan yaitu meningkatkan keimanan dan ketaqwaan anak didik kepada Allah SWT; b) Penanaman nilai yaitu sebagai pedoman hidup untuk mencapai kebahagiaan hidup di dunia; c) Penyesuaian mental yaitu untuk menyusuaikan diri dengan lingkungan fisik/sosial dan dapat mengubah lingkungannya sesuai dengan ajaran Islam; d) Perbaikan yaitu untuk memperbaiki kesalahan, kekurangan, kelemahan anak didik dalam keyakinan, pemahaman dan pengalaman ajaran dalam kehidupan; e) Pencegahan yaitu untuk menangkal phal negatif dari lingkungannya atau budaya yang dapat membahayakan dirinya dan menghambat perkembangannya; f) Penyaluran yaitu untuk menyalurka anak yang memiliki bakat khusus di bidang Pendidikan Agama Islam agar berkembang secara optimal.

Pendidikan Agama Islam disekolah adalah berfungsi untuk mengembangkan nilai-nilai agama, akhlak, dan mental peserta didik. Sehingga dapat terlihat baik dan bermanfaat untuk dirinya sendiri dan lingkungan sosialnya.

4. Faktor-Faktor Pendidikan Agama Islam

Adapun faktor-faktor pendidikan agama Islam adalah sebagai berikut :

a) Anak Didik. Anak didik adalah orang atau kelompok yang menerima pengaruh dari seseorang yang menjalankan kegiatan pengajaran Pendidikan Agama Islam. ${ }^{18}$ Pendidikan tidak akan berjalan tanpa adanya anak didik. Dalam pendidikan anak didik adalah input yang akan diproses agar menjadi sesuatu yang telah di tetapkan dalam tujuan. Untuk itu diperlukan pendidikan untuk mengarahkan anak didik ketempat yang seharusnya.

b) Pendidik. Pendidik adalah setiap orang dewasa yang karena kewajiban agamanya bertanggung jawab atas pendidikan dirinya dan orang lain. Pengertian di atas bahwa pendidik mempunyai arti yang sangat luas meliputi guru, keluarga dan masyarakat. Guru adalah pendidik yang berada di 
instasi pendidikan (sekolah) atau lebih pada tingkat formal. Keluarga adalah pendidik anak sejak dari kecil dan merupakan gerbang pertama pendidikan anak. Pendidik yang diambil disini adalah pendidik dalam lingkungan formal yaitu guru. Seorang guru mempunyai tanggung jawab yang amat besar.

c) Materi Pendidikan. Materi pendidikan agama Islam tercantum dalam Al-Quran dan Al-Hadits. Materi pokok yang diajarkan kepada anak didik adalah masalah keimanan (aqidah),masalah keislaman (syariah), masalah ihsan (akhlak). Dari ketiga materi global tersebut kemudian dijabarkan dalam rukun iman, rukun Islam dan muhsin.

d) Media Pendidikan. Media atau alat pendidikan adalah segala sesuatu yang digunakan untuk mencapai tujuan dalam pendidikan. Adapun alat/media yang dapat digunakan dalam kegiatan pembelajaran antara lain : 1) Media tanpa proyeksi tiga dimensi. Media yang penggunaannya tanpa proyektor dan mempunyai ukuran panjang, lebar dan tinggi. Contoh, boneka, model, globel dan sebagainya; 2) Media audio. Media yang hanya dapat memberikan rangsangan suara saja. Contoh, radio, tape recorder; 3) Televisi dan tape recorder. Media yang hanya dapat memberikan rangsangan suara dan gambar. Contoh, TV, vidio dan sebagainya.

e) Lingkungan. Lingkungan adalah tempat dimana pendidikan itu berlangsung. Secara langsung maupun tidak langsung lingkungan turut membantu anak didik dalam mencapai tingkat kedewasaan dan perubahan diri ke arah yang lebih baik.

f) Metode Pendidikan. Metode adalah segala usaha yang sistematis dan praktis untuk mencapai tujuan pendidikan dengan melalui berbagai aktifitas baik didalam maupun diluar kelas dalam lingkungan sekolah. Penguasaan metode yang tepat akan mudah dalam menyampaikan materi dan membawa anak didik mencapai tujuan yang ditetapkan.

g) Evaluasi. Evaluasi adalah alat untuk menentukan apakah tujuan pendidikan dan apakah proses dalam pengembangan ilmu telah berada pada jalan yang diharapkan. ${ }^{23}$ Oleh karena itu, seorang guru sebelum memberikan evaluasi kepada murid harus memperhatikan prinsip evaluasi. Hal ini karena akan menghasilkan hasil yang benar-benar dapat dipercaya. Selain itu akan dapat diketahui apakah tujuan yang diharapkan telah tercapainya telah tercapai atau belum. Dengan begitu evaluasi akan berlangsung seperti yang telah direncanakan.

\section{Media Pembelajaran}

1. Pengertian Media Pembelajaran

Media pembelajaran merupakan gabungan dari dua suku kata "media" dan "pembelajaran" istilah "media" berasal dari bahasa latin yang merupakan bentuk jamak dari "medium", yang secara harfian perantaran atau pengantar. Dari pengertian ini dapat dijelaskan bahwa media adalah segala sesuatu yang dapat menyalurkan informasi dari sumber informasi kepada penerima informasi. Dalam hal ini (Bovee, 1997) mengatakan meia adalah sebuah alat yang mempunyai fungsi menyampaikan pesan. Media menurut AECH adalah segala sesuatu yang digunakan orang untuk menyalurkan pesan.

Berdasarkan pengertian diatas, maka media pembelajaran adalah media pembelajaran adalah media yang digunakan dalam pembelajaran, sebuah alat yang berfungsi untuk menyampaikan pesan pembelajaran yang meliputi alat bantu guru dalam mengajar serta sarana pembawa pesan dari sumber belajar ke penerima pesan belajar (siswa).

\section{Fungsi Media Pembelajaran}

Secara khusus media pembelajaran memiliki fungsi sebagai berikut : 1) Menangkap suatu objek atau peristiwa-peristiwa tertentu; 2) Memanipulasi keadaan, peristiwa, dan objek tertentu; 3) Menambah gairah dan motivasi belajar siswa; 4) Memiliki nilai praktis.

\section{Klasial Media Pembelajaran}

Ada banyak macam media pembelajaran, mulai dari media yang sederhana sampai yang kompleks sekalipun. Namun, dari sekian banyak media ini, dapat diklarifikasi berdasarkan bentuk, teknik pemakaian atau kemampuannya. Dilihat dari sifat atau jenisnya media dapat dikelompokkan kepada : a) Auditif. Yaitu kelompok media yang hanya dapat didengar, atau media yang mengandalkan kemampuan suara. Media ini meliputi media radio, audio atau tape recorder; b) Media visual. Yaitu kelompok media yang hanya mengandalkan indera penglihatan seperti gambar, foto slide, kartun, 
model dan sebagainya; c) Media audio visual. Yaitu kelompok media yang dapat didengar juga dapat dilihat seperti sound slide, film, tv, vidio, dan film strip.

Dilihat dari tekhnik pemakaiannya, media dapat dikelompokkan menjadi : a) Media elektronik.adalah media yang dapat digunakan dengan bantuan alat-alat elektronik seperti projektor, tv, radio, opaque dan sebagainya; b) Media non elektronik. Yaitu yang dapat digunakan tanpa alat bantuan alat elektronik seperti grafis, gambar, model, cart, mock-up, spicemen dan sebagainya.

Dilihat dari kemampuannya dapat dibagi menjadi : a) Media yang mempunyai jangkauan dan serentak, seperti radio dan telivisi. Pemanfaatan media ini tidak terbatas pada tempat dan ruangan, siapapundapat menggunakannya dimana saja, seperti program pendidikan yang dipancar luaskan melalui satelit oleh telivisi pendidikan Indonesia; b) Media yang mempunyai jangkauan yang terbatas, seperti OHP, slide suara, film slide, dan sebagainya. Media semacam ini pemanfaatannya memerlukan tempat dan penataan ruangan yang khusus; c) Media yang hanya dapat dimanfaatkan secara indiviual, seperti model, pengajaran berprogram, pengajaran melalui komputer dan sebagainya.

Pengklasifikasian media seperti diatas, adalah pengklasifikasian secara umum yang lebih menekankan media sebagai alat, atau sumber belajar.

4. Media Audio Visual

Media Audio Visual adalah media intruksioanal modern yang sesuai dengan perkembangan zaman (Kemajuan Ilmu pengetahuan dan teknologi), meliputi media yang dapat dilihat, didengar. Media audio visual adalah jenis media yang selain mengandung unsur suara juga mengandung unsur gambar yang bisa dilihat. Misalnya rekaman video, berbagai rekaman film, slide suara, dan lain sebagainya. Kemampuan media ini dianggap lebih baik dan menarik. Penekanan utama dalam pengajaran melalui media audio visual adalah pada nilai belajar yang diperoleh melalui pengalaman konkret, tidak hanya didasarkan atas kata-kata belaka.

Teknologi audio-visual merupakan cara untuk menghasilkan atau menyampaikan meteri dengan menggunakan mesin-mesin mekanis dan elektronik untuk menyajikan pesan-pesan audio-visual. pengajaran melalui media audio visual jelas bercirikan pemakaian perangkat keras selama proses belajar seperti: televisi, tape recorder, dan proyektor visual yang lebar.

Morgan menyebutkan efektifitas pengajaran orang dewasa seperti yang disebut dalam prinsip pendidikan orang dewasa tergantung pada pengertian yang jelas. Tulisan dan ucapan sangat bermanfaat dalam situasi belajar pada umumnya, tetapi ada beberapa konsep yang tidak dapat disampaikan sejelas atau selengkap jika menggunakan alat bantu audio visual. Media audio-visual adalah media yang mempunyai unsur suara dan unsur gambar. Jenis media ini mempunyai kemampuan yang lebih baik, karena meliputi kedua jenis media yang pertama dan kedua. Media ini dibagi lagi ke dalam dua kategori, yaitu : a) Audio-visual diam yaitu: media yang menampilkan suara dan gambar diam seperti: film bingkai suara, film rangkai suara, dan cetak suara; b) Audio-visual gerak yaitu: media yang dapat menampilkan unsur suaradan gambar yang bergerak seperti: film suara dan video-cassette, televisi, OHP, dan komputer. Pengajaran melalui audio-visual adalah produksi dan penggunaan meteri yang penyerapannya melalui pandangan dan pendengaran serta tidak seluruhnya tergantung kepada pemahaman kata atau simbol-simbol yang ada.

\section{Kriteria Audio Visual}

Dalam pengelompokan audio-visual dapat dibagi menjadi dua kategori yang dapat membedakannya, antara lain : a) Media opsional atau media pengayaan. Bahannya dapat dipilih guru sesuai kehendaknya sendiri, dengan syarat cukup waktu dan biaya; b) Media yang diperlukan atau yang harus digunakan. Media macam ini harus digunakan guru untuk membantu siswa melaksanakan atau mencapai tujuan-tujuan belajar dari tugas yang diberikan.

Untuk itu diperlukan biaya dan waktu. Adapun ciri-ciri utama media audio-visual adalah sebagai berikut : a) Mereka biasanya bersifat linear; b) Mereka biasanya menyajikan visual yang dinamis; $b$ ) Mereka digunakan dengan cara yang telah ditetapkan sebelumnya oleh perancang atau pembuatnya; c) Mereka merupakan repsentasi fisik dari gagasan real dan abstrak; d) Mereka dikembangkan menurut prinsip psikologi behaviorisme dan kognitif; e) Umumnya mereka berorentasi

kepada guru dengan tingkat pelibatan interaktif murid yang rendah. 
Untuk menggunakan media audio-visual seperti yang ada sekarang masih banyak hambatannya di Indonesia. Sebabnya diantara alat-alat audio visual yang modern, ada yang memerlukan alat khusus seperti proyektor yang pada gilirannya memerlukan aliran listrik. Alat-alat audio visual dapat menyampaikan pengertian atau informasi dengan cara yang lebih konkrit atau lebih nyata dari pada ditulis. Oleh karena itu alat-alat audio visual membuat suatu pengertian atau informasi menjadi lebih berarti, lebih mudah dan lebih cepat. Belajar dengan melihat alat-alat sensori seperti gambar, bagan, contoh barang atau model. Dengan melihat dan sekaligus mendengar, orang yang menerima pelajaran, penerangan atau penyuluhan dapat lebih mudah dan lebih cepat mengerti tentang apa yang dimaksud oleh yang memberi pelajaran, penerangan atau penyuluhan.

Bahan audio-visual bisa membantu belajar dengan beberapa cara.Tapi ditinjau dari sudut penggunaanya di dalam kelas, bahan audio-visual bisa diklafikasikan dalam 2 kelompok besar yaitu : a) Media kriteria. Yaitu terdiri dari gambar-gambar, peta-peta, dan obyek-obyek sebenarnya, yang akan digambarkan atau diidentifikasikan oleh siswa untuk dapat menunjukkan bahwa ia telah menguasai bahannya. Dengan kata lain media ini merupakan bagian dari kriteria; b) Media perantara. Yaitu terdiri dari alat bantu yang bukan merupakan bagian dari situasi kriteria. Dengan kata lain siswa tidak dituntut untuk menggambarkan atau mengidentifikasikannya. Fungsi satu-satunya adalah untuk membantu siswa untuk mendapatkan pengertian tentang suatu gejala atau kejadian.

Merupakan hal yang penting untuk dapat membedakan media kriteria dari media perantara. Jika tugas media ialah untuk mempermudah belajar dengan memberi kesempatan kepada siswa melatihkan suatu keterampilan, maka media perantara membantunya untuk mendapat tersebut. Berarti kedua macam media tersebut harus digunaka dengan cara berbeda. Antara lain media perantara harus dihilangkan secara bertahap ketika terjadi belajar, sehingga siswa makin lama makin mandiri. Sebaliknya media kriteria harus dilatihkan dan diulang terus menerus supaya tidak dilupakan.

6. Jenis-Jenis Media Audio Visual

Ada beberapa jenis media yang dapat dikelompokkan dalam media audio visual, di antaranya adalah :

a) Televisi

Televisi adalah sistem elektronik yang mengirimkan gambar diam dan gambar hidup bersama suara melalui kabel atau ruang. Sistem ini menggunakan peralatan yang mengubah cahaya dan suara kedalam gelombang elektronik dan mengkonversinya kembali kedalam cahaya yang dapat dilihat dan suara yang dapat didengar. Beberapa penelitian menunjukkan bahwa siswa yang belajar melalui progam televisi untuk berbagai mata pelajaran dapat mengusai mata pelajaran tersebut sama seperti mereka yang mempelajarinya melalui tatap muka dengan guru kelas.

b) Proyektor transparasi (OHP)

Overhead projektor adalah alat audio visual yang sangat sering digunakan dalam berbagai progam pendidikan orang dewasa. ${ }^{34}$ Beberap pendidik merencanakan seluruh progam pengajaran mereka dengan menggunakan transparasi atau overhead projector. Over head projector sebaikny atidak dianggap sebagai pengganti papan tulis atau media yang lain, tetapi sebagai pelengkap saja. Bagaimanapun penggunaan overhead projector dalam pendidikan orang dewasa banyak manfaatnya.

c) Video

Video adalah gambar yang dapat dilihat atau alat komunikasi yang dapat di dengar dan dilihat. Perangkat yang digunakan sebagai audio video meliputi radio, televisi, telekomunikasi. Audio video sebagai bentuk komunikasi massa yang dikelola sebagai komunikasi agar tersebar luas sesuai dengar sasaran yang dituju, di kemas dalam bentuk berbagai komunikasi.

\section{d) Film Bersuara}

Film sebagai media audio visual adalah film yang bersuara. Slide atau film strip yang ditambah dengan suara bukan alat audio visual yang lengkap, karena suara dan rupa berada terpisah, oleh sebab itu slide atau film strip termasuk media audio visual saja atau media audio visual diam plus suara. Film yang dimaksudkan disini adalah film sebagai alat audio visual untuk pelajaran, penerangan atau penyuluhan.

e) Komputer 
Komputer adalah mesin yang dirancang khusus untuk memanipulasi informasi yang diberi kode. Mesin elektronik yang otomatis melakukan pekerjaan yang diperhitungkan sederhana dan rumit. Satu unit komputer terdiri atas empat kelompok komponen dasar, yaitu input (misal keyboard dan writingpad), prosesor (CPU: unit pemroses data yang diimput), penyimpanan data (memori yang menyimpan data yang akan diproses oleh CPU baik secara permanen (ROM) maupun untuk sementara (RAM), dan ouput (misal layar monitor, printer atau plotter). Pemanfaatan komputer untuk pendidikan yang dikenal sering dinamakan pengajaran dengan bantuan komputer (CAI) dikembangkan dalam beberapa format, antara lain drill and practice, tutorial, simulasi, permainan, dan discovery. Komputer telah pula digunakan untuk mengadministrasi tes dan pengelolaan sekolah.

\section{Kelebihan Dan Kekurangan Media Audio Visual}

Adapun kelebihan media audio visual adalah : a) Dapat memberikan suasana belajar yang lebih hidup karena penampilannya lebih menarik, dan disamping itu dapat digunakan untuk memperlihatkan suatu proses tertentu secara lebih nyata; b) Menghemat waktu penyampaian materi dan rekaman dapat diputar berulang-ulang; c) Penggunaan media ini memecahkan aspek verbalisme pada diri siswa; d) Gambar proyeksi bisa dibekukan untuk diamati dengan seksama oleh guru dan siswa karena control sepenuhnya berada ditangan guru. Sedangkan kekurangan media audio visual adalah : a) Penggunaan media ini memerlukan dukungan sarana dan prasarana tertentu; b) Membutuhkan waktu yang cukup lama pada tahapan awal untuk menyajikan materi menggunakan media; b) Pengadaan maupun pemeliharaannya cenderung menuntut tenaga dan biaya.

8. Tahapan Penggunaan Media Audio Visual

Alat-alat audio-visual baru ada faedahnya kalau yang menggunakannya telah mempunyai keahlian dan keterampilan yang lebih memadai dalam penggunaanya. Hal itu menimbulkan kepercayaan dirinya, oleh karena itu membuatnya sanggup menyampaikan pelajaran, penyuluhan atau penerangan dengan baik. Dia harus tahu bagaimana menyajikan pelajaran atau menyampaikan informasi dengan alat yang digunakannya. Adapun langka-langkahnya adalah : a) Merumuskan tujuan pengajaran dengan memanfaatkan media audio visual sebagai media pembelajaran; b) Persiapan guru. Pada fase ini guru memilih dan menetapkan media yang akan dipakai guna mencapai tujuan. Dalam hal ini prinsip pemilihan dan dasar pertimbangannya patut diperhatikan; b) Persiapan kelas. Pada fase ini siswa atau kelas harus mempunyai persiapan sebelum mereka menerima pelajaran dengan menggunakan media ini; c) Langkah penyajian pelajaran dan pemanfaatan media. Penyajian bahan pelajaran dengan memanfaatkan media pengajaran maka keahlian guru dituntut disini; d) Langkah kegiatan belajar siswa. Pada fase ini siswa belajar dengan memanfaatkan media pengajaran yang ada. Pemanfaatan media di sinisiswa sendiri mempraktekkannya ataupun guru langsung memanfaatkannya, baik di kelas atau di luar kelas; d) Langkah evaluasi pengajaran. Pada langkah ini kegiatan belajar dievaluasi, sampai sejauh mana tujuan pengajaran yang dicapai, sekaligus dapat dinilai sejauh mana pengaruh media sebagai alat bantu dapat menunjang keberhasilan proses belajar siswa.

Kehadiran media sangat membantu mereka dalam memahami konsep tertentu, yang tidak atau kurang mampu dijelaskan dengan bahasa. Ketidakmampuan guru menjelaskan sesuatu bahan itulah dapat diwakili oleh peranan media. Di sini nilai praktek media terlihat, yang bermanfaat bagi siswa dan guru dalam proses belajar mengajar.

\section{Penelitian Relevan}

Nahdiah, tahun 2014. Bahwa terjadi peningkatan dari hasil pra penelitian siswa mendapatkan nilai 66 dan setelah pelaksanaan tindakan selama dua siklus nilai siswa bertambah dengan rata-rata 75 yang secara klasikal siswa memperoleh $92 \%$.

Mufti Mirandra, tahun 2012. Bahwa terjadi peningkatan dimana hasil pelaksanaan tindakan telah memenuhi indikator yang ditetapkan yakni rata- rata siswa mendapatkan nilai rata-rata 83,33 yang secara klasikal memperoleh 94,74\%.

Amin Dariyah. Tahun 2014. Menyimpulkan bahwa mengalami kemajuan belajar dari dari hasil pra penelitian siswa mendapatkan $42,7 \%$ dan setelah pelaksanaan tindakan selama dua siklus nilai siswa bertambah dengan rata-rata $52,4 \%$ yang secara klasikal siswa memperoleh $76,1 \%$. 
Sedangkan penelitian yang akan dilakukan oleh peneliti yaitu proses pembelajaran di kelas, peneliti akan mencoba penggunaan media pembelajaran audio visual agar dalam proses pembelajaran Pendidikan Agama Islam dapat meningkatkan hasil belajar PAI melalui media audio visual pada siswa kelas IX SMPN 1 Batangtoru T.P 2020/2021 .

\section{Kerangka Berpikir}

Pembelajaran yang masih dilaksanakan guru masih bersifat konvensional yang hanya berceramah dan menggunakan metode penugasan sehingga siswa kurang tertarik dalam mengikuti pelajaran, hal ini juga mengakibatkan masih ada siswa yang nilainya belum mencapai KKM dan juga siswa kurang mengerti makna dan tujuan dari pembelajaran sehingga siswa menjadi acuh tak acuh terhadap pendidikan agama Islam terutama pada nilai karakter yang tertanam pada pelajaran pendidikan agama Islam itu sendiri. Untuk mengatasi hal tersebut di atas perlu diadakan pembenahan dalam proses pembelajaran yang dilakukan oleh guru khususnya dalam pembelajaran pendidikan agama Islam. Solusi yang saya ambil adalah dengan menerapkan media Audio Visual siswa akan lebih tertarik dan antusias dalam mengikuti pelajaran ini. Setelah penggunaan media Audio Visual maka nilai siswa dapat meningkat.

\section{Gambar 1.2 : Kerangka Berfikir}

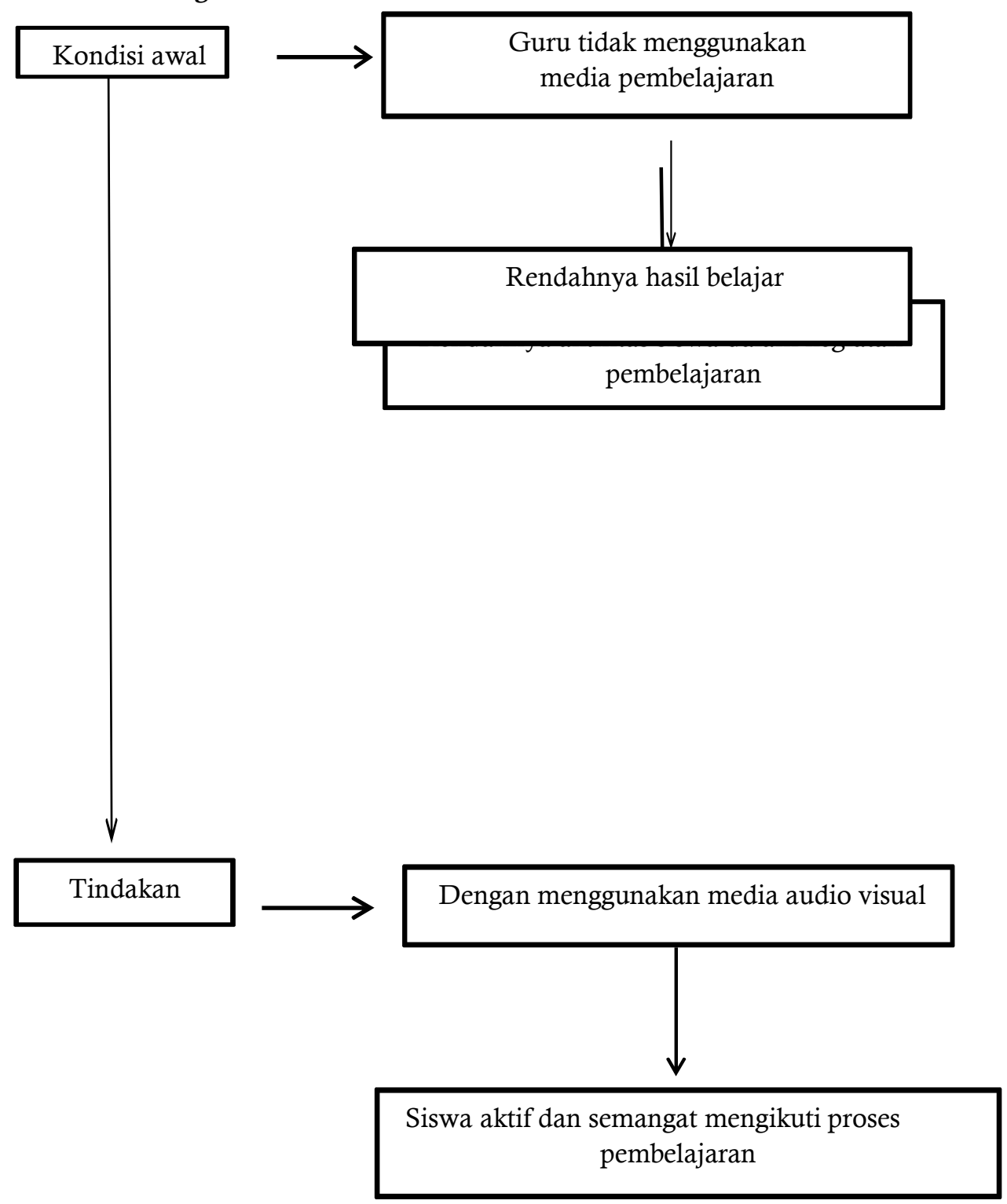




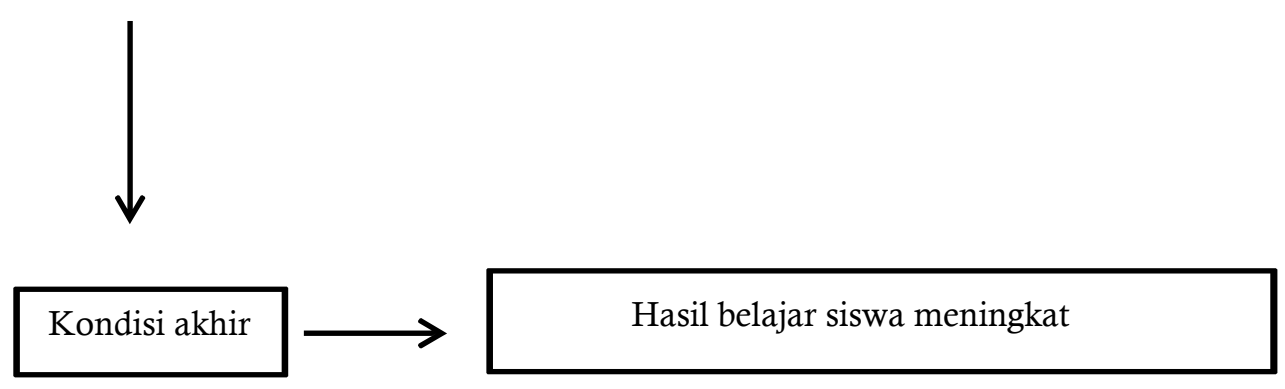

\section{Metode}

\section{Jenis Penelitian}

Jenis penelitian ini adalah penelitian tindakan kelas (PTK) yaitu penelitian yang bertujuan untuk memberikan sumbangan nyata bagi peningkatan profesionalisme guru, menyiapkan pengetahuan, pemahaman dan wawasan tentang perilaku guru mengajar dan murid belajar. Ada tiga pengertian PTK yang dapat diterangkan yaitu :

1. Penelitian, menunjuk pada suatu kegiatan mencermati suatu objek dengan menggunakan cara dan aturan metodologi tertentu untuk memperoleh data atau informasi yang bermanfaat dalam meningkatkan mutu suatu hal yang menarik minat dan penting bagi penelitian.

2. Tindakan, menunjuk pada sesuatu gerak kegiatan yang sengaja dilakukan dengan tujuan tertentu. Dalam penelitian berbentuk rangkaian siklus kegiatan untuk siswa.

3. Kelas, dalam hal ini tidak terikat pada pengertian ruang kelas, tetapi dalam pengertian yang lebih spesifik. Seperti yang sudah lama dikenal dalam bidang pendidikan dan pengajaran, yang dimaksud dengan istilah kelas disini adalah sekelompok siswa yang dalam waktu yang sama, menerima pelajaran yang sama dari guru yang sama pula.

Dengan menggabungkan ketiga kata tersebut maka Peneitian Tindakan Kelas merupakan suatu pencermatan terhadapa kegiatan belajar berupa sebuah tindakan, yang sengaja dimunculkan dan terjadi dalam sebuah kelas secara bersama. Tindakan tersebut diberikan oleh guru atau dengan arahan dari guru yang dilakukan oleh siswa.

\section{Tempat dan Waktu}

Penelitian ini dilaksanakan di SMP Negeri 1 Batangtoru tepatnya di desa Napa Kecamatan. Batangtoru pada semester ganjil tahun pelajaran 2020/2021.

\section{Subjek dan Objek Penelitian}

Penelitian ini merupakan penelitian tindakan kelas yang tidak memandang adanya populasi dan sampel karena dampak perlakuan hanya berlaku bagi subjek yang dikenai tindakan maka yang menjadi subjek penelitian dalam penelitian ini adalah siswa kelas IX-1 di SMP Negeri 1 Batangtoru tahun pelajaran 2020/2021 dengan jumlah 33 siswa. Penelitian ini dilaksanakan pada semester I tahun pelajaran 2020/2021. Sedangkan objek penelitian ini adalah pemahaman konsep pendendidikan Agama Islam pada semester I, materi zakat.

\section{Instrumen dan Teknik Pengumpulan Data}

Instrumen yang digunakan dalam penelitian ini terdiri:

1. Silabus, yaitu seperangkat rencana dan pengaturan tentang kegiatan pembelajaran pengelolaan kelas, serta penilaian hasil belajar.

2. Rencana pelaksanaan pembelajaran (RPP), yaitu perangkat pembelajaran yang digunakan sebagai pedoman guru dalam mengajar dan disusun untuk tiap putaran dan pertemuan. Masing- masing RPP berisi kompetensi dasar, indikator pencapaian hasil belajar, tujuan pembelajaran, dan kegiatan belajar mengajar dengan menggunakan metode dan model pembelajaran yang telah ditentukan.

3. Lembar Observasi, lembar observasi ini dipergunakan dalam mengamati aktifitas guru dan siswa dalam proses pembelajaran.

4. Tes Formatif, tes ini disusun berdasarkan tujuan pembelajaran yang akan dicapai, digunakan untuk mengukur kemampuan pemahaman konsep pendidikan agama Islam sesua dengan materi yang diajarkan. Tes formatif ini diberikan setiap akhir putaran. Bentuk soal yang digunakan adalah pilihan guru (objektif).

\section{Teknik Pengumpulan Data}


Pengumpulan data dalam penelitian ini menggunakan beberapa metode, yaitu sebagai berikut :

1. Observasi yaitu cara menghimpun bahan-bahan keterangan (data) yang dilakukan dengan mengadakan pengamatan dan pencatatan secara sistematis terhadap fenomena-fenomena yang sedang dijadikan sasaran pengamatan. Dalam penelitian ini, observasi dilakukan oleh peneliti dengan melakukan pengamatan terhadap aktivitas siswa dan guru selama proses pembelajaran pendidikan agama Islam dengan menggunakan media audio visual.

2. Tes. Teknik ini digunakan untuk memperoleh data dan informasi tentang hasil belajar siswa sebelum dan sesudah dilakukan instrument yang digunakan adalah soal tes yang telah disusun oleh peneliti.

3. Dokumentasi adalah cara mengumpulkan data, seperti arsip-arsip dan termasuk juga buku-buku tentang pendapat, teori, dalil atau hukum- hukum, dan nilai-nilai yang berhubungan dengan masalah-masalah penelitian. Dokumen merupakan catatan peristiwa yang sudah berlalu. Dokumen bisa berbentuk tulisan, gambar, atau karya-karya monumental dari seseorang. Dokumentasi yang dimaksud disini yaitu untuk mengetahui letak geografis, sejarah berdirinya, visi dan misi, struktur organisasi, keadaan guru dan karyawan, siswa, sarana dan prasana, serta foto-foto kegiatan pembelajaran pada siswa kelas IX-1 SMPN 1 Batangtoru.

\section{Faktor Penelitian}

Untuk menjawab permasalahan di atas, ada beberapa faktor yang diteliti yaitu : a) Faktor siswa, yaitu untuk mengetahui Faktor guru audio visual siswa kelas ]

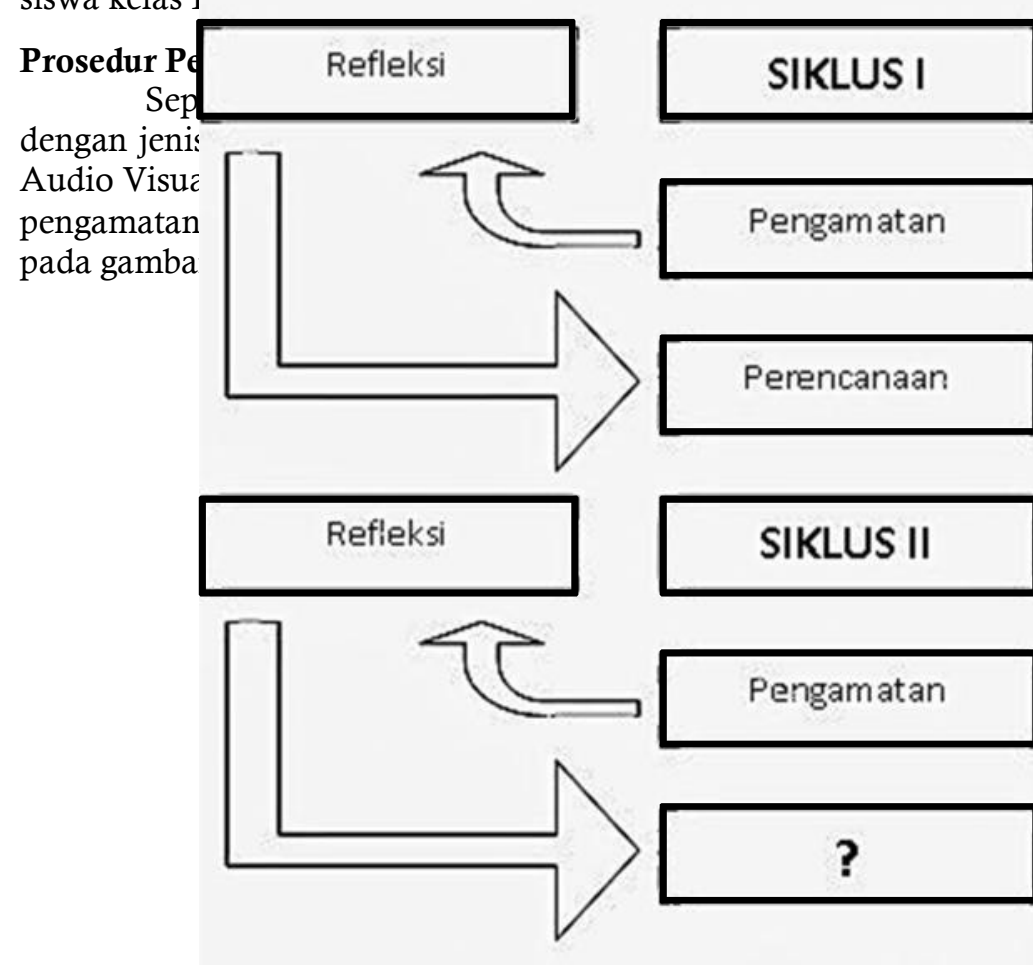




\section{Gambar 3.1: Siklus Penelitian Tindakan Kelas.}

Prosedur yang dilakukan pada penelitian tindakan kelas ini adalah sebagai berikut :

1. Siklus I

a) Perencanaan (planning)

Penelitian ini bersifat kolaboratif, yakni penelitian bersama-sama guru merencanakan tindakan. Guru bertindak sebagai pelaksana tindakan dan peneliti bertindak sebagai observasi. Adapun rincian kegiatan pada tahap perencanaan adalah sebagai berikut : 1) Bersama guru, peneliti merencanakan pembelajaran pendidikan agama Islam dengan menggunakan media audio visual yaitu vidio compac disc (VCD), vidio pembelajaran zakat yang telah di unggah di youtube; 2) Menentukan hari dan tanggal penelitian; 3) Mempersiapkan silabus, rencana pelaksanaan pembelajaran (RPP) dan LKS, yaitu tentang materi yang akan diajarkan mengenai penggunaan media audio visual pada pendidikan agama Islam; 4) Persiapan media audio visual yang akan digunakan dalam pembelajaran; 5) Menyiapkan lembar observasi, persiapan pertanyaan yang akan diajukan kepada siswa disetiap pembelajaran dan setiap siklus yang berlangsung; 6) Bersama guru mata pelajaran pendidikan agama Islam peneliti membuat persiapan soal tes untuk mengevaluasi presentasi belajar siswa setelah siklus I selesai.

b) Pelaksanaan Tindakan (action)

Pada pelaksanaan tindakan ini, guru melaksanakan desain pembelajaran pendidikan agama Islam yang telah disusun oleh peneliti sebelumnya dan telah dikonsultasikan dengan guru mata pelajaran pendidikan dikonsultasikan dengan guru mata pelajaran pendidikan agama Islam, penelitian ini dilaksanakan dalam dua siklus terdiri dari dua pertemuan.

c) Pengamatan (observasi)

Kegiatan pengamatan merupakan waktu dimana proses pengumpulan data dilaksanakan. Proses pengumpulan data ini dengan cara mengamati seluruh tindakan yang dilaksanakan. Kegiatan yang diamati meliputi sikap siswa dalam pempelajaran, suasana kelas guru dalam menyampaikan materi, interaksi antara guru dengan siswa, interaksi siswa dengan siswa, dan hal-hal yang terjadi pada saat proses pembelajaran berlangsung. Pengumpulan data ini dilakukan dengan menggunakan lembar observasi yang sudah disusun. Untuk mengetahui jalannya pembelajaran, maka peneliti mempersiapkan lembar observasi.

d) Evaluasi

Siswa diberikan soal-soal evaluasi baik tertulis maupun lisan pada akhir dari kegiatan pembelajaran nilai yang diperoleh siswa selanjutnya dianalisis untuk pelaksanaan tindakan.

e) Refleksi

Refleksi ini dilaksanakan untuk mengetahui pelaksanaan tindakan baik yang bersifat positif maupun negatif. Pelaksanaan refleksi berupa diskusi antara guru pendidikan agama Islam dan peneliti. Dalam refleksi ini dilakukan dengan cara mengumpulkan serta mengidentifikasikan data yang diperoleh peneliti selaku observasi. Kemudian peneliti merumuskan perencanaan untuk siklus selanjutnya.

\section{Siklus II}

Tahap-tahap yang dilaksanakan pada pembelajaran siklus dua ini mengikuti kegiatan pembelajaran yang telah dilakukan pada siklus I. Dalam hal ini, rencana siklus II disusun berdasarkan hasil refleksi pada siklus I. Adapun kegiatan yang dilakukan pada siklus ini sebagai penyempurnaan terhadap pelaksanaan pembelajaran pendidikan agama Islam dengan menggunakan media audio visual pada siklus I.

\section{Teknik Analisis Data}

Analisis data adalah proses mencari dan menyusun secara sistematis data yang diperoleh dari hasil wawancara, catatan lapangan dan bahan-bahan lain sehingga mudah dipahami. Penelitian ini menggunakan analisis deskriptif kuantitatif dan kualitatif, yakni menggambarkan dan menggunakan angka dan kalimat untuk memperoleh keterangan yang jelas dan terperinci. Proses analisis data pada dasarnya melalui beberapa tahap analisis yaitu :

1. Penyajian data yaitu proses dimana data yang telah diperoleh, diidentifikasikan dan dikategorisasikan kemudian disajikan dengan cara mencari kaitan antara suatu kategori dengan kategori lainnya. 
2. Penarikan kesimpulan dan verifikasi merupakan tahapan mencari arti benda-benda, mencatat keteraturan, pola-pola, penjelasan konfigurasi-konfigurasi yang mungkin alur sebab akibat dan proporsi. Sedangkan verifikasi merupakan tahap untuk menguji kebenaran, kekokohan, dan kecocokan.

Data yang telah dianalisis disajikan dalam bentuk tabel dengan tujuan data mudah dibaca dan dipahami, hasil belajar akan dilihat dari nilai rata-rata kelas, KKM, nilai tertinggi dan terendah. Adapun rumus yang digunakan oleh penulis dalam menganalisa data tersebut adalah sebagai berikut:

1. Untuk mengukur besarnya perolehan nilai rata-rata skor hasil belajar murid sebagai gambaran peningkatan hasil belajar digunakan rumus:

$$
\frac{\sum X^{i}}{N}
$$

Keterangan:

$$
\begin{array}{ll}
\mathrm{X} & =\text { Mean /nilai Rata-Rata } \\
\sum_{\mathrm{N}} X_{\Gamma}^{\boldsymbol{i}} & =\text { Skor Setiap Siswa } \\
\mathrm{N} & =\text { Jumlah Siswa }
\end{array}
$$

2. Selanjutnya data dideskripsikan dengan menggunakan rumus presentase

$$
\begin{array}{ll} 
& \mathrm{P}=\frac{\sum \times \mathrm{F} 100 \%}{\mathrm{~N}} \\
\text { Keterangan }: & \\
\mathrm{P}=\text { Persentase hasil belajar } \\
\mathrm{F}=\text { Frekuensi yang sedang dicari persentasenya } \mathrm{N}=\text { Jumlah } \\
\text { siswa. }
\end{array}
$$

3. Peningkatan hasil belajar pendidikan agama Islam pada tia siklus yang menggambarkan peningkatan hasil, guna mengetahui hasil secara maksimal dibutuhkan analisis kuantitatif sebagai alat uji peningkatan hasil belajar dengan rumus:

$\mathrm{P}=$

$$
=100 \% \quad \frac{\text { posrate-basrate }}{\text { basrate }}
$$

Keterangan :

$$
\begin{aligned}
& \mathrm{P} \quad=\text { Presentase Peningkatan } \\
& \text { Posrate } \quad \text { Nilai Yang Sudah Diberikan Tindakan Basrate = } \\
& \text { Nilai Sebelum Tindakan. }{ }^{7}
\end{aligned}
$$

Dengan tolak ukur refleksi penelitian tindakan kelas ini adalah sebagai berikut : a) Adanya peningkatan hasil belajar yang terlihat pada saat maupun akhir proses pembelajaran pada setiap siklus dengan pengelolaan kelas yang telah diberikan; b) Adanya peningkatan nilai akhir yang diperoleh siswa pada setiap siklus.

\title{
Indikator Keberhasilan
}

Sebagai standar keberhasilan dari penelitian ini adalah ditunjukan dengan peningkatan hasil belajar yang diraih oleh murid melalui peningkatan hasil belajar siswa pada mata pelajaran Pendidikan Agama Islam melalui penggunaan media audio visual, dengan skala ukur keberhasilan mencapai kategori $85 \%$ maka dalam hal ini siswa dinyatakan mencapai keberhasilan hasil belajar Pendidikan Agama Islam secara klasikal, dan dikatakan telah mencapai keberhasilan hasil belajar secara individu apabila indikator belajar siswa telah mendapatkan skala ukur keberhasilan kategori $\geq 70$.

\section{Hasil Penelitian dan Pembahasan}

\author{
Hasil Penelitian \\ Gambaran Umum Lokasi Penelitian \\ Profil SMP Negeri 1 Batangtoru
}


Nama Sekolah

Alamat Sekolah

No. Telp

E-mail

Kabupaten

Provinsi

No. Statistik Sekolah

NPSN

Tipe Sekolah

No Akreditasi

Tanggal Akreditasi

Telepon

Status Sekolah

Visi Sekolah

Kepeserta didikan Berlandaskan Iman dan Taqwa serta peduli lingkungan ”

Indikator :

$>$ Terwujudnya peningkatan kegiatan keagamaan di sekolah

$>$ Terwujudnya prestasi akademis yang meningkat dari tahun ke tahun

$>$ Terwujudnya $100 \%$ kelulusan.

$>$ Terwujudnya juara dalam berbagai lomba tingkat Kabupaten/ propinsi

$>$ Terwujudnya keunggulan dalam disiplin dan kegiatan ekstra kurikuler

$>$ Terwujudnya lingkungan sekolah aman, bersih, tertib, indah, rindang, dan sehat diliputi rasa kekeluargaan

$>$ Terwujudnya suasana sekolah yang konduif.

Misi SMP Negeri 1 Batangtoru sebagai berikut :

* Berprestasi secara akademik dan non akademik melalui proses pembelajaran yang bermakna

* Mengembangkan pendidikan karakter bangsa

* Manajemen pengelolaan sekolah yang akuntable dan transparan.

* Meningkatkan keimanan dan ketaqwaan kepada Tuhan Yang Maha Esa.

* Menciptakan lingkungan sekolah yang sehat, bersih, indah dan menyenangkan.

* Mewujudkan lingkungan yang kondusif.

* Meningkatkan kerjasama dan peran serta orang tua/komite

Tujuan

Berdasarkan Visi dan misi yang telah dirumuskan SMP Negeri 1 Batangtoru

mempunyai tujuan :

1. Peningkatan terhadap pencapaian rata-rata Nilai Ujian Akhir, sehingga peserta didik mampu bersaing dalam memasuki jenjang pendidikan selanjutnya.

2. Memiliki tim kesenian yang mampu tampil pada acara setingkat kabupaten/kota dan Nasional

3. Memiliki kemampuan mengoperasikan computer.

4. Memiliki tim olah raga yang mampu menjadi finalis tingkat kabupaten / kota.

5. $95 \%$ peserta didik Muslim lulusan memiliki kemampuan membaca al-Qur'an.

6. Menjadikan warga sekolah patuh dan taat dalam menjalankan agamanya.

7. Menjadikan warga sekolah yang sopan dan disiplin.

8. Memiliki kemampuan dalam mengembangkan kurikulum berbasis kompetensi.

9. Terpenuhinya sarana dan prasarana pendidikan.

10. Terciptanya manajemen sekolah yang akuntabel, transparan dan partisiptif.

11. Tersedianya biaya pendidikan sesuai dengan anggaran yang dibutuhkan.

\section{Pengamatan Pendahuluan}

Penelitian yang dilaksanakan peneliti adalah penelitian tindakan kelas (PTK). Peneliti sekaligus sebagai guru mata pelajaran di kelas IX-1 SMP Negeri 1 Batangtoru. Peneliti menggunakan Media Audio Visual dalam pembelajaran daring, dikarenakan media pembelajaran yang menarik dan inovatif yang sesuai dengan kondisi belajar peserta didik pada masa pandemic COVID-19 yang menggunakan pembelajaran DARING. Sehingga pembelajaran yang selama ini dilaksanakan oleh guru lebih sering menggunakan metode penugasan. Hasil belajar peserta didik pada mata pelajaran Pendidikan Agama Islam masih kurang optimal, yaitu masih banyaknya nilai peserta didik yang dibawah KKM. Data yang diperoleh ada 13 peserta didik yang nilainya tuntas, sedangkan yang tidak tuntas adalah sebanyak 20 peserta didik. Berdasarkan permasalahan di atas, 
maka penelitian yang PAI dan BP dilakukan menggunakan media pembelajaran audio visual, Pembelajaran PAI dan BP dalam pelaksanaannya melibatkan keaktifan dari semua peserta didik dalam pembelajaran daring sehingga semua peserta didik dapat memiliki keterampilan sosial, dapat memperoleh informasi, serta dapat belajar mandiri yang akan membentuk peserta didik yang kreatif dan inovatif nantinya. Dengan penerapan pembelajaran PAI dan BP dengan media audio visual dalam kegiatan pembelajaran di kelas, diharapkan akan bisa menimbulkan penguasaan akademik untuk meningkatkan motivasi dan hasil belajar peserta didik.

Pelaksanaan pembelajaran PA dan BP dengan menggunakan media audio visual ini peneliti dibantu oleh dua orang guru sebagai observer yaitu, Ibu masraya Harahap,SPdI dan Bapak Hasyril Syam Chaniago, SAg. Penelitian ini dilaksanakan dalam dua siklus, dimana siklus satu terdiri dari 2 kali pertemuan dan siklus 2 terdiri dari dua kali pertemuan. Tiap pertemuan berlangsung 2 × 30 menit atau selama 60 menit. Pelaksanaan pembelajaran berlangsung setiap hari Rabu untuk sesi A dan Kamis untuk sesi B tepatnya pada jam $8.00 \mathrm{~s} / \mathrm{d}$ 8.30 WIB. Rincian lebih lengkap seperti pada tabel 1 berikut:

Tabel 4 Rincian Tindakan Kelas

\begin{tabular}{lllll}
\hline NO & Hari/Tanggal & Siklus & Pertemuan & Jenis Kegiatan \\
1. & Rabu, 02-09-2020 & I & 1 & Pre Test dan Kegiatan Pembelajaran \\
& Kamis, 03-09-2020 & & & $\begin{array}{l}\text { Kegiatan pembelajaran } \\
\text { Post test }\end{array}$ \\
2. & $\begin{array}{l}\text { Rabu, 09-09-2020 } \\
\text { Kamis, 10-09-2020 }\end{array}$ & I & 2 & Kegiatan Pembelajaran \\
4. & $\begin{array}{l}\text { Rabu, 16-09-2020 } \\
\text { Kamis, 17-09-2020 }\end{array}$ & II & 1 & $\begin{array}{l}\text { Kegiatan Pembelajaran } \\
\text { Postest }\end{array}$ \\
5. & & & \\
\hline
\end{tabular}

Kegiatan pembelajaran setiap siklusnya didampingi oleh guru Pendidikan Agama Islam sebagai observer yaitu Ibu Masraya, S.Pd. Tugas dari observer tersebut adalah menilai dan mengamati proses pembelajaran yang sedang berlangsung dengan menggunakan lembar pengamatan guru dan peserta didik. Hasil belajar peserta didik yang dilihat dari aspek kognitif diukur dengan menggunakan tes akhir pada setiap akhir siklus.

\section{Siklus I}

Pelaksanaan pembelajaran pada siklus I terdiri atas tiga tahap yakni perencanaan, pelaksanaan, observasi, dan refleksi. pelaksanaan pada siklus I ini dilaksanakan selama dua kali pertemuan yaitu dimulai dari tanggal 02 September 2020 sampai dengan 04 September 2020 Dalam siklus I ini, peneliti ingin melihat perkembangan peningkatan hasil belajar yang dimiliki peserta didik dengan pembelajaran PAI dan BP dengan menggunakan media pembelajaran audio visual. Apabila hasil belajar meningkat dengan menggunakan media pembelajaran audio visual, maka perkembangan kemampuan akademik pun akan tercapai sesuai dengan KKM. Demikian sebaliknya, maka akan dilanjutkan pada siklus II.

\section{Perencanaan Tindakan Siklus I}

Pada siklus I dilakukan beberapa tahapan tindakan. Tahapan-tahapan tindakan pada siklus I terdiri atas perencanaan tindakan dan pelaksanaan tindakan, selanjutnya menyusun rencana tindakan siklus I. Langkahlangkah dalam menyusun rencana tindakan pada siklus satu adalah menyiapkan perangkat pembelajaran berupa silabus, rencana pelaksanaan pembelajaran (RPP), lembar observasi keterlaksanaan pembelajaran oleh guru, lembar observasi keterlaksanaan oleh peserta didik, media pembelajaran audio visual zakat yang di share ke you tube, tes hasil belajar kognitif berupa test on line, dokumentasi berupa print screen ketika pembelajaran di zoom.

Perencanaan Tindakan pada siklus I ini, dipersiapkan secara sistematis. Karena pada tahap perencanaan akan menentukan hasil akhir dari proses pembelajaran. Tahap perencanaan disusun seperti biasa layaknya guru akan memberikan pengajaran pada peserta didik dengan menyiapkan semua yang dibutuhkan dalam proses belajar mengajar. Setelah tahap perencanaan disusun secara sistematis, tahap selanjutnya adalah tahap pelaksanaanya.

\section{Pelaksanaan Tindakan Siklus I}

a. Pertemuan ke 1 


\section{1) Kegiatan awal}

Pertemuan pertama dilaksanakan pada hari Sabtu 03 September 2020 jam pertama dan kedua yang berlangsung di kelas IX-1. Peneliti memulai pertemuan mengucapkan salam dan menanyakan kabar peserta didik lalu meminta ketua kelas untuk memimpin doa di google classroom, kemudian mengabsen kehadiran peserta didik. Berikutnya persentase menyampaikan tentang tujuan pertemuan hari ini. Selanjutnya memotivasi peserta didik untuk menjaga kesehatan dan melakukan 3M (mencuci tangan, memaka masker, dan menjauhi kerumunan). Pertemuan kali ini peserta didik diajak untuk memperhatikan Ibadah Zakat melalui media audio visual yang di share di google classroom dengan membagikan tautan you tube ke google classroom. Kemudian guru mempersilahkan melakukan tanya jawab untuk identifikasi masalah, kemudian dengan identifikasi masalah dibuatlah kelompok : kelompok 1 membahas tentang apa itu zakat dan hukumnya. Kelompok 2 membahas jenis jenis zakat, kelompok 3 membahas perhitungan zakat fitrah dan dan kelompok terakhir tentag hikmah zakat .

\section{2) Kegiatan inti}

Pada kegiatan inti peneliti membagikan pre test untuk diisi peserta didik. Setelah peserta didik selesai mengisi pre test dan menjelaskan kembali materi zakat. Pada pertemuan awal ini peneliti membagi peserta didik menjadi beberapa kelompok yang secara heterogen sesuai dengan kemampuan belajar, juga mengirimkan kembali materi ke peserta didik dengan memutar kembali media audio visual yatu vidio materi zakat .

\section{3) Kegiatan akhir}

Pada kegiatan akhir ini, peneliti bersama-sama dengan peserta didik membuat rangkuman/ kesimpulan pelajaran dan memberikan umpan balik terhadap proses dan hasil pembelajaran. meminta kepada peserta didik untuk membaca serta mempelajari materi zakat. Kemudian peneliti menutup pertemuan dengan mengucapkan salam.

\section{b. Pertemuan ke 2 \\ 1) Kegiatan awal}

Pertemuan ke dua dilaksanakan pada hari Rabu, 09 September 2020, Jam pertama dan kedua dengan alokasi waktu belajar 2 x 30 menit. Pada kegiatan awal ini peneliti memulai pelajaran dengan mengucapkan salam dan menanyakan kabar peserta didik di zoom. Kemudian guru duduk dan memerintahkan ketua kelas untuk memimpin doa sebelum memulai pelajaran. Setelah doa selesai guru mengabsen kehadiran peserta didik lalu menyampaikan tujuan pembelajaran, kemudian guru menjelaskan secara singkat garis besar materi yang akan dipelajari pada hari ini.

\section{2) Kegiatan inti}

Pada kegiatan inti, guru membagi kelompok belajar dengan menggunakan model pembelajaran discovery learning. Dalam kegiatan eksplorasi dan analisis di kelompok peserta didik tentang pengertian, dalil, hukum, jenis-jenis zakat, serta cara perhitungan zakat fitrah, serta hikmah zakat. Pada kegiatan komunikasi peserta didik mempresentasikan hasil kelompoknya. Setelah masing-masing kelompok mempresentasikan hasil pencarian dan analisisnya, dan ditanggapi oleh kelompok lain. Guru memberikan a plus kepada kelompok yang kreatif dalam meyampaiakan hasil diskusinya yang berupa peta konsep yang berwarna warni yang ditunjukkan fotonya di google classroom atau dijelaskan dalam bentuk vidio di google classroom.

\section{3) Kegiatan akhir}

Pada kegiatan inti ini, guru membagikan post test yang bertujuan untuk menetukan hasil belajar peserta didik pada periode siklus I berupa test on line. Pada kegiatan akhir ini, guru sebagai peneliti mengakhiri post test serta mengumpulkan hasil tersebut dari peserta didik. Guru sebagai peneliti menjelaskan materi yang akan dipelajarai pada pertemuan berikutnya serta kembali mengingatkan kepada peserta didik untuk menjaga kesehatan dengan tiga $\mathrm{M}$. Setelah itu guru mengucapkan salam dan menutup dengan doa.

\section{Observasi Siklus I}

Pada pelaksanaan pembelajaran, peneliti dibantu oleh satu orang guru dari sekolah SMP N 1 Batangtoru sekaligus sebagai guru mata pelajaran Pendidikan Agama Islam yaitu Ibu Masraya, S.Pd. Guru tersebut membantu peneliti sebagai observer yang mengamati kegiatan proses pembelajaran yang dilaksanakan oleh peneliti. Dalam pengamatannya observer mengisi lembar observasi yang telah dibuat oleh peneliti yaitu lembar keterlaksanaan pembelajaran oleh guru dan peserta didik. Berdasarkan hasil dari pelaksanaan tindakan pada siklus I diperoleh data sebagai berikut : 
a. Keterlaksanaan Pembelajaran

Keterlaksanaan pembelajaran meliputi, keterlaksanaan pembelajaran oleh guru dan keterlaksanaan pembelajaran oleh peserta didik.

1) Keterlaksanaan pembelajaran oleh guru

Keterlaksanaan pembelajaran oleh guru terdiri dari tiga tahapan yaitu, tahap awal, tahap inti, dan tahap akhir. Secara singkat persentase keterlaksanaan pembelajaran oleh guru dapat dilihat pada tabel 4.5 berikut :

Tabel 5 Tabel Keterlaksanaan pembelajaran oleh guru pada siklus I

\begin{tabular}{llll}
\hline Pertemuan & I & II & III \\
\hline Observer & 1 & 1 & 1 \\
Skor (\%) & 71,76 & 75,49 & 78,82 \\
Skor rata-rata (\%) & & Baik & \\
Kriteria & & & \\
\hline \multicolumn{2}{l}{ Sumber: data diolah) } & &
\end{tabular}

Berdasarkan data tabel 4.5 Dapat dilihat bahwa keterlaksanaan pembelajaran oleh guru berjalan dengan baik. hal ini ditunjukan dengan rata-rata persentase keterlaksanaan pembelajaran oleh guru sebesar $78,82 \%$. Berdasarkan data ini dapat disimpulkan bahwasannya keterlaksanaan pembelajaran PAI dan BP pada pelaksanaan di siklus I berjalan dengan baik.

2) Keterlaksanaan pembelajaran oleh peserta didik

Secara singkat persentase keterlaksanaan pembelajaran oleh peserta didik dapat dilihat pada tabel 4.6 berikut :

Tabel 6 Tabel Keterlaksanaan pembelajaran oleh peserta didik pada siklus I

\begin{tabular}{lll}
\hline Pertemuan & I & II \\
\hline Observer & 1 & 1 \\
Skor (\%) & 66,66 & 75 \\
Kriteria & & Baik \\
\hline
\end{tabular}

(Sumber: data diolah)

Berdasarkan data tabel 4.6 Dapat dilihat bahwa keterlaksanaan pembelajaran oleh guru berjalan dengan baik. hal ini ditunjukan dengan skor rata-rata persentase keterlaksanaan pembelajaran oleh guru sebesar $75 \%$ dengan kriteria baik. Berdasarkan data ini dapat disimpulkan bahwasannya keterlaksanaan pembelajaran kooperatif oleh peserta didik pada pelaksanaan di siklus I berjalan dengan baik.

\section{b. Hasil belajar peserta didik}

Hasil belajar peserta didik dalam penelitian tindakan kelas yang dilakukan hanya mengukur pada ranah konigtif. Hasil belajar peserta didik diukur dengan menggunakan tes hasil belajar berbentuk soal pilihan ganda sebanyank 10 soal. Mengenai hasil belajar peserta didik dianalisis dengan menghitung jumlah peserta didik yang telah tuntas tes di akhir siklus I. sedangkan ketuntasan klasikal dihitung dari jumlah peserta didik yang belajar dibagi dengan jumlah peserta didik yang mengikuti tes dikali dengan 100\%. Setelah dilakukan tes ternya ada sejumlah peserta didik yang belum mencapai KKM yang sudah ditentukan sekolah. Dari pihak sekolah KKM ditentukan sebesar 75, dari tes yang dilakukan sejumlah peserta didik yang telah mencapai KKM sebanyak 20 peserta didik dan 13 peserta didik masih belum mencapai KKM. dapat dihitung bahwa persentase ketuntasan belajar sebesar 60,61 \% sedangkan yang belum tuntas dalam belajar 39,39\%. dari hasil tersebut bahwasannya belum dapat mencapai pada ketuntasan klasikal, sebab dapat dikatakan tuntas apabila telah mencapai ketuntasan sebesar $80 \%$. Hasil belajar peserta didik dapat dilihat pada tabel 4.7

Tabel 7 Hasil Belajar Peserta didik Akhir Siklus I

\begin{tabular}{llll}
\hline Rentang Nilai & Frekuensi & Persentase & Kategori \\
\hline $75-100$ & 20 & 60,61 & Tuntas \\
$<75$ & 13 & 39,39 & Belum Tuntas \\
\hline
\end{tabular}

Sumber: Data diolah

\section{Refleksi Siklus I}


Refleksi pada siklus I ini dilakukan peneliti untuk mengetahui kekurangan dan kelebihan pelaksanaan pembelajaran dengan menggunakan media audio visual. Dari pelaksanaan refleksi inilah dijadikan bahan pertimbangan peneliti untuk perbaikan dan pelaksanaan pada siklus II. Hasil yang didapat dari dua observer yang membantu peneliti dalam pembelajaran ternyata masih terdapat kekurangan dan kelebihan pelaksanaan pembelajaran dengan menggunakan media audio visual. Adapun kekurangan dan kelebihan dalam pelaksanaan pembelajaran pada siklus I adalah :

1. Kekurangan pada siklus I

a. Peserta didik masih banyak yang bingung dalam pelaksanaan pembelajaran dikarenakan baru pertama kali melakukan pembelajaran daring dengan menggunakan audio visual.

b. Peserta didik masih cenderung passif ketika diskusi.

c. Pada saat pembelajaran ada beberapa siswa yang tidak bisa mengikuti karena hpnya lagi dipakai orang tua bekerja.

2. Kelebihan pada siklus I

a. Setelah dilaksanakan semua tahapan pembelajaran, rasa ingin tahu yang tinggi dari peserta didik dalam mengikuti pembelajaran dengan menggunakan media audio visual.

b. Terjadinya peningkatan hasil belajar Pendidikan Agama Islam setelah dilaksanakan pembelajaran dari sebelum tindakan dan setelah dilaksanakan tes akhir siklus I

Dari hasil refleksi yang dilaksanakan pada siklus I, selanjutnya peneliti menyusun tahap-tahap pelaksanaan pembelajaran siklus II. Tahapan-tahapan pada siklus II ini diharapkan akan lebih baik lagi dari pada siklus I.

\section{Siklus II}

Pelaksanaan pembelajaran pada siklus II terdiri atas empat tahap yakni perencanaan, pelaksanaan, observasi, dan refleksi. pelaksanaan pada siklus II ini dilaksanakan selama 2 kali pertemuan yaitu pada tanggal 16 September 2020 dan 23 September 2020.

\section{Perencanaan Tindakan Siklus II}

Pada siklus II dilakukan beberapa tahapan tindakan. Tahapan-tahapan tindakan pada siklus II terdiri atas perencanaan tindakan dan pelaksanaan tindakan, selanjutnya menyusun rencana tindakan siklus II. Langkah-langkah dalam menyusun rencana tindakan pada siklus II adalah menyiapkan perangkat pembelajaran berupa silabus, rencana pelaksanaan pembelajaran (RPP), lembar observasi keterlaksanaan pembelajaran oleh guru, lembar observasi keterlaksanaan oleh peserta didik, angket motivasi belajar, kartu soal, tes hasil belajar kognitif, kamera untuk dokumentasi. Perencanaan Tindakan pada siklus II ini, dipersiapkan secara sistematis. Karena pada tahap perencanaan akan menentukan hasil akhir dari proses pembelajaran. Tahap perencanaan disusun seperti biasa layaknya guru akan memberikan pengajaran pada peserta didik dengan menyiapkan semua yang dibutuhkan dalam proses belajar mengajar. Setelah tahap perencanaan disusun secara sistematis, tahap selanjutnya adalah tahap pelaksanaanya.

2. Pelaksanaan Tindakan Siklus II

\section{a. Pertemuan ke 1}

1) Kegiatan awal

Pertemuan ke satu dilaksanakan pada hari Rabu, 16 September 2020 jam pertama dan kedua dengan alokasi waktu belajar 2 x 30 menit. Pada kegiatan awal ini peneliti, memulai pelajaran dengan mengucapkan salam dan menanyakan kabar peserta didik saat ini, berdoa yang kesemuanya di lakukan di zoom.

\section{2) Kegiatan inti}

Pada kegiatan inti ini, guru memberikan penjelasan kembali tentang pembelajaran zakat dengan media audio visual pada pertemuan siklus 1, agar peserta didik dapat lebih mengerti. Untuk mengawali pembelajaran, diadakan tanya jawab untuk mengidentifikasi kedalaman pengetahuan siswa. Setelah itu guru mengarahkan peserta didik untuk mengenal kelompoknya masing-masing yang terdiri dari 5 orang anggota yang telah dibentuk pada pertemuan awal. Tahap berikutnya guru memutarkan vidio pembelajaran tentang zakat. Peserta didik menyimak vidio pembelajaran tersebut. Kemudian beserta kelompoknya mengisi LKP atau lembar tugas kelompok .

\section{3) Kegiatan akhir}

Guru melakukan kegiatan penutup bersama-sama peserta didik untuk membut kesimpulan dari materi yang telah ditonton tadi. Guru juga memberi kesempatan kepada peserta didik untuk bertanya tentang materi, Peserta didik menjawab "sudah paham bu". Kemudian guru mengucapkan salam kepada peserta didik tanda berakhirnya materi pada pertemuan kali ini. Dan mengingatkan hasil diskusi akan di presentasikan di zoom selanjutnya yatu tanggal 25 September 2020. 


\section{b. Pertemuan ke 2 \\ 1) Kegiatan awal}

Pertemuan ke dua dilaksanakan pada hari rabu 23 September 2020 jam pertama dan kedua dengan alokasi 2 x 30 menit atau selama 60 menit yaitu 8.00 s/d 9.00 WIB. Kegiatan awal pada pertemuan ke dua ini dimulai dengan guru mengucapkan salam, lalu bertanya kepada peserta didik "bagaimana kabarnya hari ini?" baru berdoa yang semuanya di lakukan di zoom. Kemudian setiap kelompok mula mempersiapkan presentasinya tentang zakat sesua dengan panduan kerja kelompok yang telah di isi pada pertemuan yang lalu.

\section{2) Kegiatan inti}

Pada kegiatan inti ini, setiap kelompok melakukan presentase sekitar 5 menit.

Kemudian peserta didik saling menanggapi ketika temannya mempresentasikan hasil diskusi kelompoknya. Di akhir diskusi gur memberikan a plus bagi kelompok dengan jawaban terbaik dan memotivasi kelompok lan supaya tetap semnagat. Kemudian gur melakukan penguatan materi. Lalu Guru memberikan petunjuk tentang tata cara pengisian soal tes akhir. Guru juga memberikan pengarahan agar dalam mengerjakan soal dikerjakan sendiri-sendiri tidak boleh bekerja sesama teman, tidak boleh membuka buka catatan dan buku paket, dengan jujur. Semua peserta didk keluar dari zoom menuju google classroom untuk melakukan post test.

\section{3) Kegiatan akhir}

Pemeriksaan post test oleh guru di google classroom.

\section{Observasi Siklus II}

Pada pelaksanaan pembelajaran, peneliti dibantu oleh dua orang guru dari sekolah SMP Negeri 1 Batangtoru yaitu Masraya, S.Pd. dan Bapak Hasyril syam chaniago, Sag, Guru tersebut membantu peneliti sebagai observer yang membantu mengamati kegiatan proses pembelajaran yang dilaksanakan oleh peneliti. Dalam pengamatannya observer mengisi lembar observasi yang telah dibuat oleh peneliti yaitu lembar keterlaksanaan pembelajaran oleh guru dan peserta didik. Berdasarkan hasil dari pelaksanaan tindakan pada siklus II diperoleh data sebagai berikut :

\section{Keterlaksanaan Pembelajaran}

Keterlaksanaan pembelajaran meliputi, keterlaksanaan pembelajaran oleh guru dan keterlaksanaan pembelajaran oleh peserta didik.

a. Keterlaksanaan pembelajaran oleh guru

Keterlaksanaan pembelajaran oleh guru terdiri dari tiga tahapan yaitu, tahap awal, tahap inti, dan tahap akhir. Secara singkat persentase keterlaksanaan pembelajaran oleh guru dapat dilihat pada tabel 4.8 berikut:

Tabel 8 Tabel Keterlaksanaan pembelajaran oleh guru pada siklis II

\begin{tabular}{lcc}
\hline Pertemuan & I & II \\
\hline Observer & 1 & 1 \\
Skor $(\%)$ & 83,52 & 85,88 \\
Kriteria & & Sangat Baik \\
\hline
\end{tabular}

Sumber: data diolah

Berdasarkan data tabel 4.8 Dapat dilihat bahwa keterlaksanaan pembelajara oleh guru berjalan dengan sangat baik. Hal ini ditunjukan dengan persentase keterlaksanaan pembelajaran oleh guru sebesar $85,88 \%$. Berdasarkan data ini dapat disimpulkan bahwasannya keterlaksanaan pembelajaran materi zakat dengan menggunakan audio visual oleh guru pada pelaksanaan di siklus II berjalan dengan sangat baik.

b. Keterlaksanaan pembelajaran oleh peserta didik

Secara singkat persentase keterlaksanaan pembelajaran oleh peserta didik dapat dilihat pada tabel 4.9 berikut :

Tabel 9 Tabel Keterlaksanaan pembelajaran oleh peserta didik pada siklus II

\begin{tabular}{lc}
\hline Pertemuan & $\mathrm{I}$ \\
\hline Observer & 1 \\
Skor (\%) & 88,33 \\
Skor rata-rata (\%) & \\
\hline
\end{tabular}




\begin{tabular}{lc}
\hline Kriteria & Sangat baik \\
\hline Sumber: data diolah &
\end{tabular}

Berdasarkan data tabel 4.9 Dapat dilihat bahwa keterlaksanaan pembelajaran oleh guru berjalan dengan sangat baik. hal ini ditunjukan dengan skor persentase keterlaksanaan pembelajaran oleh guru sebesar 88,33\% dengan kriteria sangat baik. Berdasarkan data ini dapat disimpulkan bahwasannya keterlaksanaan pembelajaran PAI dan BP dengan materi zakat dengan menggunakan media audio visual di siklus II berjalan dengan sangat baik.

\section{Hasil belajar peserta didik}

Hasil belajar peserta didik dalam penelitian tindakan kelas yang dilakukan hanya mengukur pada ranah konigtif. Hasil belajar peserta didik diukur dengan menggunakan tes hasil belajar berbentuk soal pilihan ganda sebanyank 10 soal. Mengenai hasil belajar peserta didik dianalisis dengan menghitung jumlah peserta didik yang telah tuntas tes di akhir siklus II. sedangkan ketuntasan klasikal dihitung dari jumlah peserta didik yang belajar dibagi dengan jumlah peserta didik yang mengikuti tes dikali dengan $100 \%$. Setelah dilakukan tes ternya ada sejumlah peserta didik yang belum mencapai KKM yang sudah ditentukan sekolah. Dari pihak sekolah KKM ditentukan sebesar 75, dari tes yang dilakukan sejumlah peserta didik yang telah mencapai KKM sebanyak 30 peserta didik dan 3 peserta didik masih belum mencapai KKM. Dapat dihitung bahwa persentase ketuntasan belajar sebesar 90,91\% sedangkan yang belum tuntas dalam belajar 9,09\% dari hasil tersebut bahwasannya sudah dapat mencapai pada ketuntasan klasikal, sebab dapat dikatakan tuntas apabila telah mencapai ketuntasan sebesar $80 \%$. Hasil belajar peserta didik dapat dilihat pada tabel 4.10.

Tabel 10 Hasil Belajar Peserta didik Akhir Siklus II

\begin{tabular}{lccc}
\hline Rentang Nilai & Frekuensi & Persentase & Kategori \\
\hline $75-100$ & 30 & $90,91 \%$ & Tuntas \\
$<75$ & 3 & 9,09 & Belum Tuntas \\
\hline
\end{tabular}

Sumber: Data diolah

\section{Refleksi Siklus II}

Refleksi pada siklus II dilakukan peneliti untuk mengetahui kekurangan dan kelebihan pelaksanaan pembelajaran PAI dan BP dengan materi zakat dengan menggunakan media audio visual. Berdasarkan pengamatan obeserver, pelaksanaan pembelajaran PAI dan BP dengan materi zakat dengan menggunakan media audio visual di akhir siklus II sudah berjalan sangat baik yang ditandai adanya:

a. Pada pelaksanaan pembelajaran berlangsung sudah tidak ada lagi di temukan peserta didik yang kebingungan.

b. Peserta didik sudah berani mengemukakan pendapat dalam menjawab pertanyaan yang diajukan oleh teman sejawatnya dalam diskusi di zoom.

c. Hasil belajar peserta didik juga mengalami peningkatan dengan nilai akhir siklus II terdapat 30 peserta didik yang tuntas dan 3 peserta didik yang belum tuntas. Persentase hasil belajar ketuntasan secara klasikal adalah $90,91 \%$.

Dari hasil refleksi pada siklus II maka dapat disimpulkan pelaksanaan pembelajaran pembelajaran PAI dan BP dengan materi zakat dengan menggunakan media audio visual sudah berhasil dan berjalan dengan sangat baik. dari hasil yang sangat baik ini maka peneliti tidak perlu lagi melakukan pembelajaran ke siklus berikutnya.

\section{Temuan Penelitian}

Berdasarkan analisis data pelaksanaan pembelajaran PAI dan BP dengan materi zakat dengan menggunakan media audio visual di akhir siklus I dan akhir siklus II terjadi peningkatan. Adapun keterlaksanaan peningkatan pembelajaran PAI dan BP dengan materi zakat dengan menggunakan media audio visual, hasil belajar peserta didik adalah sebagai berikut :

a. Keterlaksanaan kegiatan pembelajaran

Keterlaksanaan pembelajaran dilakukan oleh guru dan peserta didik yang di amati oleh observer yang mengurusi lembar observasi menunjukkan peningkatan di akhir siklus I dan akhir siklus II. Keterlaksanaan pembelajaran oleh guru dan peserta didik seperti pada tabel 4.11 di bawah.

Tabel 11 Keterlaksanaan pembelajaran oleh guru dan peserta didik

\begin{tabular}{llll}
\hline Keterlaksanaan Pembelajaran & \% siklus I & \% siklus II & \% keterlaksanaan \\
\hline Guru & 75,49 & 85,29 & 9,8 \\
\hline
\end{tabular}




\begin{tabular}{llll}
\hline Peserta didik & 74,72 & 85 & 10,28 \\
\hline Rata-rata & 75,11 & 85,15 & 10,04 \\
\hline
\end{tabular}

Sumber: Data diolah

b. Hasil belajar peserta didik

Mengetahui hasil belajar peserta didik adalah dengan tes tulis dalam bentuk pilihan ganda sebanyak 10 soal kepada peserta didik. Berdasarkan hasil analisis hasil tes belajar peserta didik terjadi peningkatan mulai dari sebelum tindakan, tes akhir siklus I, dan tes akhir siklus II. Peningkatan hasil tes belajar peserta didik dapat dilihat pada tabel 4.12 di bawah :

Tabel 12 Peningkatan hasil belajar peserta didik

\begin{tabular}{lccccc}
\hline Kegiatan & \multicolumn{2}{c}{ \% Ketuntasan } & \% Kenaikan & $\begin{array}{c}\text { \% Ketuntasan } \\
\text { Siklus II }\end{array}$ & \% Kenaikan \\
\cline { 2 - 3 } & $\begin{array}{c}\text { Sebelum } \\
\text { Tindakan }\end{array}$ & Siklus I & & & \\
\hline $\begin{array}{l}\text { Hasil } \\
\text { Belajar }\end{array}$ & 39,39 & 60,61 & 21,22 & 90,91 & 30,3 \\
\hline
\end{tabular}

Sumber: Data diolah

Berdasarkan tabel 4.12 bahwa ada peningkatan hasil belajar peserta didik dari mulai sebelum tindakan sampai dengan akhir siklus II. Pelaksanaan sebelum tindakan ada 13 peserta didik yang tuntas belajarnya dengan persentase secara klasikal adalah 39,39 \%, sedangkan meningkat pada akhir siklus I ada 20 peserta didik yang tuntas belajarnya dengan persentase secara klasikal adalah $60,61 \%$, dan meningkat kembali pada akhir siklus II ada 30 peserta didik yang tuntas dalam belajar dengan persentase ketuntasan klasikalnya adalah 90,91\%. Dapat ditarik kesimpulan bahwasannya hasil belajar peserta didik pada pembelajaran PAI dan BP dengan materi zakat dengan menggunakan media audio visual sudah tercapai secara klasikal.

\section{Pembahasan}

Media Audio pada Mata Pelajaran Pendidikan Agama Islam

Media pembelajaran adalah media yang digunakan dalam pembelajaran, sebuah alat yang berfungsi untuk menyampaikan pesan pembelajaran yang meliputi alat bantu guru dalam mengajar serta sarana pembawa pesan dari sumber belajar ke penerima pesan belajar (siswa). Media Audio Visual adalah media intruksioanal modern yang sesuai dengan perkembangan zaman (Kemajuan Ilmu pengetahuan dan teknologi), meliputi media yang dapat dilihat, didengar. Penekanan utama dalam pengajaran melalui media audio visual adalah pada nilai belajar yang diperoleh melalui pengalaman konkret, tidak hanya didasarkan atas kata-kata belaka. Banyak jenis media pembelajaran audio visual, namun dalam hal ini penulis menitik beratkan pada vidio pembelajaran yang dirancang untuk menyampaikan pesan dan materi pembelajaran PA dan BP. Penggunaan media pembelajaran audio visual pada pembelajaran PAI dan BP dimaksudkan agar dalam proses pembelajaran Pendidikan Agama Islam dapat meningkatkan hasil belajar PAI dan memudahkan siswa dalam menyerap materi serta memudahkan pembelajaran daring yang menggunakan media elektonik HP dan laptop.

Penggunaan Media Audio pada Mata Pelajaran Pendidikan Agama Islam dan Budi Pekerti dapat Meningkatkan Hasil Belajar Peserta Didik pada Materi Zakat di Kelas IX-1 T.P 2020/2021

Belajar adalah aktivitas mental/psikis yang berlangsung dalam interaksi aktif dengan lingkungan yang yang menghasilkan perubahan-perubahan dalam pengetahuan, keterampilan dan sikap (Winkel dalam Purwanto, 2014). Salah satu cara untuk menilai keberhasilan pelaksanaan kegiatan belajar mengajar di kelas yang harus dilakukan guru dan peserta didik adalah dengan melihat atau mengetahui hasil belajar. Hasil belajar merupakan suatu penguasaan hasil perubahan tingkah laku (Hamalik, 2008).

Hasil belajar dalam penelitian ini adalah hasil belajar peserta didik pada ranah kognitif. Tes hasil belajar peserta didik pada ranah kognitif berbentuk soal pilihan ganda sebanyak 20 soal. Untuk mengetahui tingkat ketuntasan individu dilakukan dengan skor yang diperoleh peserta didik dibagi skor maksimal dikali 100\%. Sedangkan kriteria ketuntasan maksimal yang ditentukan sekolah adalah 75 . Untuk mengukur ketuntasan secara klasikal adalah jumlah peserta didik yang memperoleh skor $\geq 75$ dibagi dengan jumlah seluruh peserta didik. Dalam penelitian ini hasil belajar diperoleh dari tes yang dilakukan pada akhir siklus yang dilakukan dalam dua siklus. 
Berdasarkan hasil analisis data, dengan menggunakan audio visual pada pembelajaran PAI dan BP pada materi Zakat di kelas IX-1 dalam pembelajaran daring dapat dilihat hasilnya, Pelaksanaan sebelum tindakan ada 13 peserta didik yang tuntas belajarnya dengan persentase secara klasikal adalah 39,39\%, hasil ini semakin meningkat pada akhir siklus I, dimana ada 20 peserta didik yang tuntas belajarnya dengan persentase secara klasikal adalah 60,61 \%, dan meningkat kembali pada akhir siklus II,dengan tuntasnya 30 peserta didik dalam belajar dengan persentase ketuntasan klasikalnya adalah 90,91\%. Dapat ditarik kesimpulan bahwasannya hasil belajar peserta didik pada pembelajaran PAI dan BP dengan materi zakat dengan menggunakan media audio visual sudah tercapai secara klasikal.

\section{Kesimpulan}

Hasil penelitian, observasi, evaluasi dan refleksi pada setiap siklus tindakan yang telah diuraikan pada bab sebelumnya maka disimpulkan bahwa menggunakan media audio visual pokok bahasan "zakat" khususnya semester ganjil kelas IX-1 SMP Negeri 1 Batangtoru tahun pelajaran 2020/2021, bahwa hasil belajar siswa dapat ditingkatkan. Hal ini ditunjukkan pada presentase nilai siswa setelah tindakan meningkat, jika pada pra siklus persentase nilai peserta didik 39,39\% , maka pada siklus satu persentase nila peserta didk tersebut meningkat menjadi $60,61 \%$. Namun belum mencapai indikator kinerja yang telah ditetapkan. Selanjutnya pada siklus II semakin meningkatkan dari siklus I yaitu dari 60,61 \% menjadi 90,91\%. dan telah memenuhi indikator kinerja yang telah ditetapkan sebelumnya, yaitu $85 \%$ klasikal dan siswa telah mencapai nilai minimal 70

\section{Referensi}

Abdullah, Saleh Abdurrahman. (1990). Teori Pendidikan Menurut Alquran, Jakarta: Rineka Cipta.

Andayani, Dian, Majid Dan Abdul. (2004). Pendidikan Agama Islam Berbasis Kompetensi, Bandung: PT Remaja Rosda Karya.

Azizy, Qodri, A. (2003). Pendidikan Agama Untuk Membangun Etika Sosial, Semarang: Aneka Ilmu.

Aly, Neo Hery. (2009). Ilmu Pendidikan Agama Islam, Jakarta: Logos.

Aliwar. (1999). Media Pembelajaran, Kendari:CV.Shadra.

Arsyad, Azhar. (2009). Media Pembelajaran, Jakarta:PT Raja Grafindo Persada.

Arikunto, Suharsimi, Penelitian Tindakan Kelas, Jakarta: Bumi Aksara

Arsyad, Azhar. (2002). Media Pembelajaran, Jakarta: Raja Grafindo Persada.

Akdon, Ridwan. (2007). Rumus Dan Data Dalam Analisis Statistika, Bandung: Alfabeta.

Basyirudin, Usman, Asnawir, Media Pembelajaran, Jakarta: Ciputat Pers, 2002.

Akib, Jainal Dkk. (2001). Penelitian Tindakan Kelas Untuk Guru SMA,SMP DAN SMK, Alam Widya.

Depag RI. (1994. GBPP Pendidikan Agama Islam Edisi 1994, Jakarta: Departemen Agama RI.

Daradja, Zakiah. (2002). Ilmu Pendidikan Islam, Jakarta: PT Rosda Karya,

Muhaimin Dkk.. (2002).Paradigma Pendidikan Islam, Upaya Mengaktifkan PAI Disekolah, Bandung: PT Remaja Rosda Karya,

Dariyah, Amin. (2014). Upaya Meningkatkan Kemampuan Sholat Melalui Media Audio Visual Pada Siswa Kelompok A2 TK ABA Sidomuliyo II Bambangglupuro Bantul, .Bantul:

IQ, Agustina. (2006).Prestasi Belajar, Dan EQ, (Jurnal Provitae), Vol. 2, No. 2, November

Mudhofir. (1999). Teknologi Instruksional, Bandung: Remaja Rosdakarya.

Munadi, Yudhi. (2008). Media Pembelajaran, Jakarta : Gaung Persada Press,

Meria Ramadhani, Komputer Multimedia HYPERLINK, http//www.google.com.

Mirandra, Mufti. (2012). Penggunaan Media Audio Visual Dalam Meningkatkan Prestasi Belajar Ilmu Pengetahuan Alam Kelas III B MI Sananul Ula Piyungan Bantul, .Bantul :

Margono, S. (2004). Metode Penelitian Pendidikan, Jakarta: Rineka Cipta.

Munadi, Yhudi. (2010). Media Pembelajaran; Sebuah Pendekatan Baru, Jakarta: Gaung Persada Press.

Nahdiah. (2014). Penggunaan Media Audio Visual Dalam Meningkatkan Hasil Belajar Siswa Kelas VII Pada Mata Pelajaran Fikihdi MTS Fatahillah Buncit Jakarta Selatan, Jakarta Selatan

Observasi Prapenelitian, Ditunjukan Sebagai Langkah Awal Untuk Mengidentifikasikan Temuan Masalah Berkaitan Dengan Penerapan Media Untuk Meningkatkan Hasil Belajar Murid, Yang Menjadi Argumen Teoritis Pentingnya Sebuah Variabel Penelitian Diangkat. (Observasi Pra-Penelitian Pada Tanggal I6 februari Di SMP Negeri 12 Kendari).

Rohani, Ahmad. (1997). Media Intruksional Edukatif, Jakarta: Rineka Cipta. 
Rifai, Ahma dan Sudjana, Nana. (1989). Teknologi Pengajaran, Bandung: SInar Baru Offset. Slameto. Sistem Evaluasi. (2001). Jakarta: PT. Bumi Aksara, Sadiman, S, Arief dkk. (1986). Media Pendidikan, Jakarta: Raja Grafindo Persada Sanjaya, Wina. (2007). Strateegi Pembelajaran Berorientasi Standar Proses Pendidikan, Jakarta Suprijanto. (2007). Pendidikan Orang Dewasa dari Teori Hingga Aplikas, Jakarta: Bumi Aksara. Sudiyono, Anas. (2014). Pengantar Statistik Pendidikan, Jakarta: Grafindo Persada.

Sudjana, Nana. (2010). Penilaian Hasil Proses Belajar Mengajar, Bandung: Remaja Rosda Karya. Suharsimi, Arikunto, Dkk. 2006. Penelitian Tindakan Kelas, Jakarta: Bumi Aksara. Slameto. (2003). Belajar Dan Faktor-Faktor Yang Mempengaruhinya, Jakarta: Rineke Cipta. Tafsir, Ahmad. (1992). Metode Khusus Pendidikan Agama Islam, Bandung: Remaja Rosda Karya, W.Gulo. (2002). Strategi Belajar Mengajar, Jakarta: PT Grasindo. Zuhairini. (1998). Metodik Pendidikan Islam, IAIN Tarbiyah Sunan Ampel Press: Malang. Zaian, Azwan, Djamarah, Bahri, Syaiful. (2002 Strategi Belajar Mengajarm, Jakarta: Rhineka Cipta. 